\title{
ICT investment and economic growth in India: An industry perspective
}

\author{
K L Krishna \\ Email: krishna@econdse.org \\ Centre for Development Economics, \\ Delhi School of Economics \\ Abdul A Erumban \\ Email: abdul.erumban@confernce-board.org \\ The Conference Board and University of Groningen \\ Bishwanath Goldar \\ Email: b_goldar77@yahoo.com \\ Former Professor, Institute of Economic Growth, Delhi, India \\ Deb Kusum Das \\ Email: dkd_ramjas@yahoo.com \\ Ramjas College, University of Delhi, India \\ Suresh Chand Aggarwal \\ Email: sureshchag@yahoo.com \\ Former Professor, Department of Business Economics \\ University of Delhi, South Campus, India \\ Pilu Chandra Das \\ Email: arpiludas@gmail.com \\ Kidderpore College, University of Calcutta
}

\section{Working Paper No. 284}

http://www.cdedse.org/pdf/work284.pdf

\section{CENTRE FOR DEVELOPMENT ECONOMICS}

DELHI SCHOOL OF ECONOMICS 


\title{
ICT investment and economic growth in India: An industry perspective
}

\author{
K L Krishna ${ }^{0}$, Abdul A Erumban ${ }^{1}$, Bishwanath Goldar ${ }^{3}$, Deb Kusum Das ${ }^{4}$, \\ Suresh Chand Aggarwal ${ }^{2}$, and Pilu Chandra Das ${ }^{5}$
}

\begin{abstract}
The role of information and communication technologies (ICT) in driving economic growth has been well established in the literature. By reducing communication and transaction costs, and improving the quality of capital, ICT helps firms improve their productivity and growth. Given her linguistic and engineering skills, India has been pioneering in ICT exports, in particular export of software services since the 1990s. However, there is hardly any attempt to understand how Indian industries have been taking advantage of the massive growth potential of ICT use in their production process, looking into the experiences of different industries. This has been primarily constrained by lack of adequate, disaggregated data on the ICT use by industries. While there are a few studies trying to understand the contribution of ICT to aggregate economic growth, almost no study has attempted to unearth the role of ICT at detailed industry level. This paper is a first attempt to construct ICT investment series for the registered or organized segment of manufacturing industries in India, and one of the first few attempts that have made so far to build such ICT series for the aggregate Indian economy. The study extends the capital asset database in India KLEMS to include ICT investment, i.e. investment in hardware, software and communication equipment, in respect of different manufacturing industries. The paper also provides preliminary estimates of the contribution of ICT capital to growth in aggregate economy and registered manufacturing sector.
\end{abstract}

Keywords: India; economic growth; information technology; ICT; organized manufacturing; industrywise investment, aggregate economy

0. Centre for Development Economics, Delhi School of Economics, Delhi. 1. The Conference Board and University of Groningen, abdul.erumban@conference-board.org; 2.Former Professor, Institute of Economic Growth, Delhi, India, b_goldar77@yahoo.com; 3. Department of Economics, Ramjas College, University of Delhi, India,dkd_ramjas@yahoo.com; 4.Former Professor, Department of Business Economics, University of Delhi, South Campus, India, sureshchag@yahoo.com; 5.Kidderpore College, University of Calcutta, arpiludas@gmail.com.

Acknowledgements: This paper draws heavily on the India KLEMS project funded by the Reserve Bank of India. The authors are thankful to the Reserve Bank, and many researchers who have contributed to the development of this data. In particular, we thank K.L. Krishna for his comments and contributions. Comments by participants of the India KLEMS Conference at the Delhi School of Economics in December 2016, in particular Ashok Jain, T. Rajeshwari, Rajiv Mehta and S.Sahoo were quite beneficial to this work. Research assistance by Gunajit Kalita and SreerupaSengupta are also acknowledged. Views expressed in this paper are those of the authors and do not reflect their respective institutions. The usual disclaimers apply. 


\section{Introduction}

The role of information and communication technologies (ICT) in driving economic growth has been well established in the literature (see for instance Jorgenson et al, 2011; Inklaar et al., 2008; Jorgenson and $\mathrm{Vu}, 2005$; Jorgenson et al, 2005; van Ark et al, 2003; Jorgenson, 2001). ${ }^{1}$ By reducing communication and transaction costs, and improving the quality of capital, ICT helps firms improve their productivity and growth. In Figure 1, we depict the ratio of ICT investment to GDP in 81 countries over the period 1990-2015 against labor productivity growth. It is quite evident that there is a strong correlation between the two. Even more important is that this correlation is stronger in the emerging market economies, and remains strong even if we exclude outlier countries. It is also evident that the emerging market economies are quite behind in ICT adoption, compared to most advanced economies. This clearly suggests that these economies still have significant potential for improving their productivity growth by investing in ICT.

\footnotetext{
${ }^{1}$ For a while, productivity statistics failed to capture the effect of ICT, as the rapid declines in ICT prices and information on ICT investment were not fully captured in official data. In 1987 Robert Solow even remarked, "[Y]ou can see the computer age everywhere except in the productivity statistics", an observation which is often considered as "IT productivity paradox". However, later studies which accounted for rapid declines in ICT prices using qualityadjusted hedonic prices observed significant contributions from ICT (see e.g. Jorgenson and Vu, 2005). The debate on price is, however, far from settled. For instance, a recent study by Byrne and Corrado (2016), argues that the official US hedonic prices fail to capture the magnitude of price declines in ICT, and their alternative measures suggest even larger declines.
} 
Figure 1: Correlation between ICT investment and labor productivity growth, 1990-2015

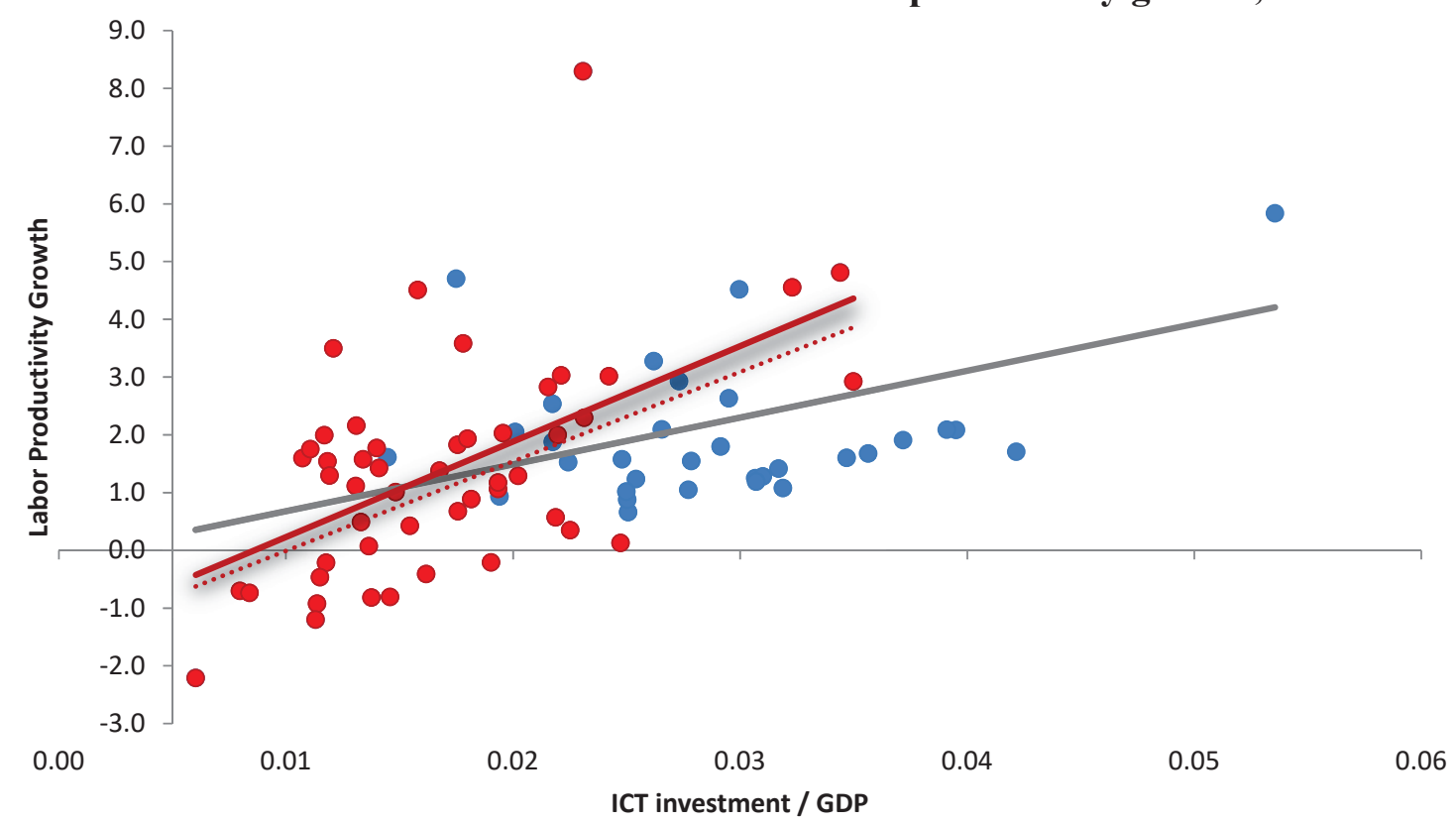

Note: The red dots are emerging markets and the blue dots are advanced economies. The gray solid line is the linear trend line for the entire 81 countries, and the red solid line is the linear trend line for emerging market economies only. The red dotted line is the trend line for emerging market economies only, but excluding outlier countries.

Source: The Conference Board Total Economy Database, November 2016

Given her linguistic and engineering skills, India has been pioneering in ICT exports, in particular export of software services since the 1990s. Taking its early bird advantage, India has maintained a relatively higher market presence in the software segment of IT industry (Saith, Vijayabaskar, 2005). However, there is hardly any attempt to understand how Indian industries have been taking advantage of the growth potential of ICT use in their production process. While there are a few studies trying to understand the contribution of ICT to aggregate economic growth ${ }^{2}$, the evidence on the ICT's impact on growth at detailed industry level is even more limited. Available micro level evidence based on plant or firm level data is suggestive of a positive impact of ICT on growth and productivity in India's organized manufacturing sector. For instance, Sharma and Singh (2012), using ICT investment data from ASI, observe that higher ICT stock is associated with higher levels of value added. Similar conclusions have been made by Joseph and Abraham (2007), who observe a positive effect of ICT investment intensity on both labor productivity and

\footnotetext{
${ }^{2}$ See Erumban and Das (2016) for a most recent analysis of ICT's contribution to aggregate economy growth.
} 
TFP, even though the ICT intensity in the sector is low. Comparing firms in India and Brazil, Commander et al (2011) suggest the importance of better infrastructure and labor market policy for higher rates of ICT adoption. These policies might be imperative for increasing the ICT intensity in India's manufacturing, which is arguably low, as is evidenced by previous studies. Kite (2012 and 2013) observe positive ICT effects on productivity, and in particular the use of outsourced ICT makes larger contribution than in-house ICT. ${ }^{3}$ A recent paper by Navyashree and Bhat (2016) analyzes the ICT investments and its growth effects in small and medium firms in food processing industry in India. Using Prowess data, they demonstrate a positive impact of ICT use on growth of small and medium enterprises. At a more aggregate level, Erumban and Das (2016) provide estimates of ICT contribution to growth for the aggregate manufacturing. They use ASI and NSSO data on ICT investment, respectively for registered and unregistered segments of the manufacturing sector. Their findings suggest a lower contribution of ICT to growth in the manufacturing, compared to the aggregate economy, thus implicitly suggesting a larger ICT contribution in the services sector.

Two recent studies looked at ICT in Indian economy from a different perspective, which are Mitra et al (2016) and Vashisht (2017). Mitra et al (2016) looks at the importance of ICT infrastructure for productivity growth in Indian manufacturing. While their study does not have any explicit measure of ICT capital (they have a measure of total capital stock based on CMIE's Prowess data, which is obtained using a perpetual inventory method assuming 7 percent depreciation rate), they evaluate the impact of ICT infrastructure on productivity, with the ICT infrastructure data being obtained from World Bank's World Development Indicators. Vashisht (2017) looks at the job impact of technology, where ICT is considered as one of the major technologies. They find no evidence of technology destroying jobs, rather their evidence is suggestive of it shifting jobs from intermediary skill to high skill jobs. While technology has led to an increase in the capital intensity, it has not reduced aggregate employment in Indian manufacturing. They use ICT investment data reported in ASI - the same data as we use in this paper (see the discussion below) - in constructing ICT capital stock.

\footnotetext{
${ }^{3}$ IT outsourcing in these studies is measured using data on expenditure on software and other professional services obtained from PROWESS.
} 
Thus the evidence on ICT's impact on economic growth in India is quite limited. The major reason for this, despite India being one of the major ICT service providers, is the lack of adequate consistent data on the ICT use by industries. Since the onset of India KLEMS database, which provides detailed asset wise information on capital investment at industry level, along with other indicators required to analyze sources of growth, it is now feasible to examine the sources of economic growth in India at detailed industry level. ${ }^{4}$ This study intends to extend the India KLEMS data to include ICT investment, i.e. investment in hardware, software and communication equipment, in the aggregate economy and in the organized manufacturing industries. While the India KLEMS is an exhaustive database, covering all segments of the economy - be it organized or unorganized - due to data limitations, the current version of the paper will analyze the role of ICT in the organized manufacturing industries only, using detailed asset data from Annual Survey of Industries (ASI). Note that the India KLEMS data is fully benchmarked to National Accounts Statistics (NAS) data. The basic estimates of industry wise ICT investment data in this paper is consistent with ASI, and is subsequently benchmarked to NAS data to ensure consistency. Future extension may attempt to extend it to other India KLEMS industries, including unorganized manufacturing and services.

Following the economic liberalization and large scale globalization policies in the early 1990s, India has benefitted from the second unbundling of globalization - the ICT revolution that has radically lowered transmission costs (see for instance Baldwin 2016). As Erumban and Das (2016) noted, Indian's English language ability, engineering and programming skills accompanied by lower labor cost helped the country catch-up quite fast, particularly in the software sector. Existing evidence suggests that the ICT revolution has helped several Indian firms introduce innovative entrepreneurship and governance model within the software sector (Arora and Athreye, 2002). Going beyond the software producing sector, the use of ICT is expected to reduce communication and co-ordination costs in ICT using industries, and thereby help them improve their productivity. Following previous literature, Erumban and Das (2016) summarizes the channels through which ICT can contribute to economic growth, which includes: a production channel, in which ICT producing sectors benefit from rapid technological change in the sector; an investment channel, in which firms investing in ICT could enhance the contribution of capital to

\footnotetext{
${ }^{4}$ See Das et al (2016) for a recent study that exploit this database to study sectoral productivity dynamics in Indian economy.
} 
growth, and a productivity channel, in which firms using ICT could improve their productivity. ${ }^{5} \mathrm{To}$ understand these channels better, we need to have industry-wise data on investment in ICT, along with output, employment and investment in other types of capital assets. While the India KLEMS provides all but the ICT, this paper is an attempt to fill this gap.

The remaining of the paper is presented in four sections. The second section discusses the methodology to estimate ICT investment for Indian economy. First it discusses the approach to estimate aggregate economy ICT investment, and the trends in estimated ICT investment series. Subsequently it presents the approach used to derive a series on investment in ICT for the organized (registered) manufacturing industries covered by the Annual Survey of Industries (ASI). The results are also discussed in the section. In Section 3, we discuss some practical aspects or issues that need to be tackled while incorporating the estimated series of ICT investment into India KLEMS growth accounting database. In section 4 we provide some preliminary results on our estimation of the contribution of ICT capital to growth in aggregate economy and registered manufacturing. In the latter case, following the India KLEMS practice, to keep full consistency with National Accounts (NAS) data, the obtained ICT series for ASI sector has been normalized to NAS aggregate GFCF data. In section 5, we provide a summary of main findings, and in the last section we discuss the way forward.

\section{Estimating ICT investment in Indian Economy ${ }^{6}$}

There is hardly any official data on complete ICT investment series, covering hardware, software and communication equipment, in India. Therefore, it is essential to estimate a series of ICT investment compiling various sources of information. We follow a three-step approach in estimating ICT investment for the Indian economy. First, we estimate the investment in hardware, software and communication equipment in the aggregate economy, which is consistent with available data from the National Accounts Statistics (NAS). Then we estimate industry-wise investment for the organized manufacturing industries - i.e. 13 India KLEMS manufacturing industries. In the third step, we combine the two series, by which the manufacturing sector

\footnotetext{
${ }^{5}$ Also see van Ark et al (2011)

${ }^{6}$ The discussion in this section on aggregate economy ICT investment heavily draws upon Erumban and Das (2016). This paper is an extension of Erumban and Das (2016) in that it constructs ICT capital in detailed manufacturing sectors, though confined only to the registered segment.
} 
estimates are benchmarked to National Accounts data. In what follows we discuss the approaches we follow to estimate aggregate economy series and organized manufacturing sector series separately.

\subsection{Approach to estimating aggregate economy ICT investment}

The available information on ICT investment in India include software investment from NAS since 1999-00, ASI's ICT investment series in organized manufacturing sectors since 1998, NSSO $62^{\text {nd }}$ round data on ICT investment in unorganized manufacturing, CMIE's PROWESS firm level data on gross fixed assets in hardware, software and communication equipment (1989 onwards) and World Information Technology and Services Alliance (WITSA) ${ }^{7}$ 's estimates on ICT spending by broad sectors of the economy since 2000. In this paper, we make use of NAS, ASI and WITSA data, along with investment flows by commodities reported in Input-Output Tables (to be discussed later).

Software investment: National Accounts Statistics provides software investment by different undertakings covering administrative departments, autonomous bodies, cooperatives, departmental enterprises, household sector, non-departmental enterprises, private corporate sector and public administration, since 1999. We have obtained this data disaggregated by industries from Central Statistics Office (CSO), and this has been the basic series we consider as the benchmark series of software investment for India. A comparison of CSO's software series with that of ICT spending data from WITSA suggests a substantial downward bias in WITSA software spending data. For instance, for 2008, WITSA software spending to GDP ratio is 0.12 percent, excluding consumer spending and 0.17 percent including consumer spending, whereas NAS software investment/GDP ratio from National Accounts is 1.2 percent.

\footnotetext{
${ }^{7}$ WITSA provides ICT spending data in a cross section of countries through their Digital Planet Report. See http://www.witsa.org/
} 
Figure 2: Ratio of investment in software to hardware (current price), aggregate economy the three approaches

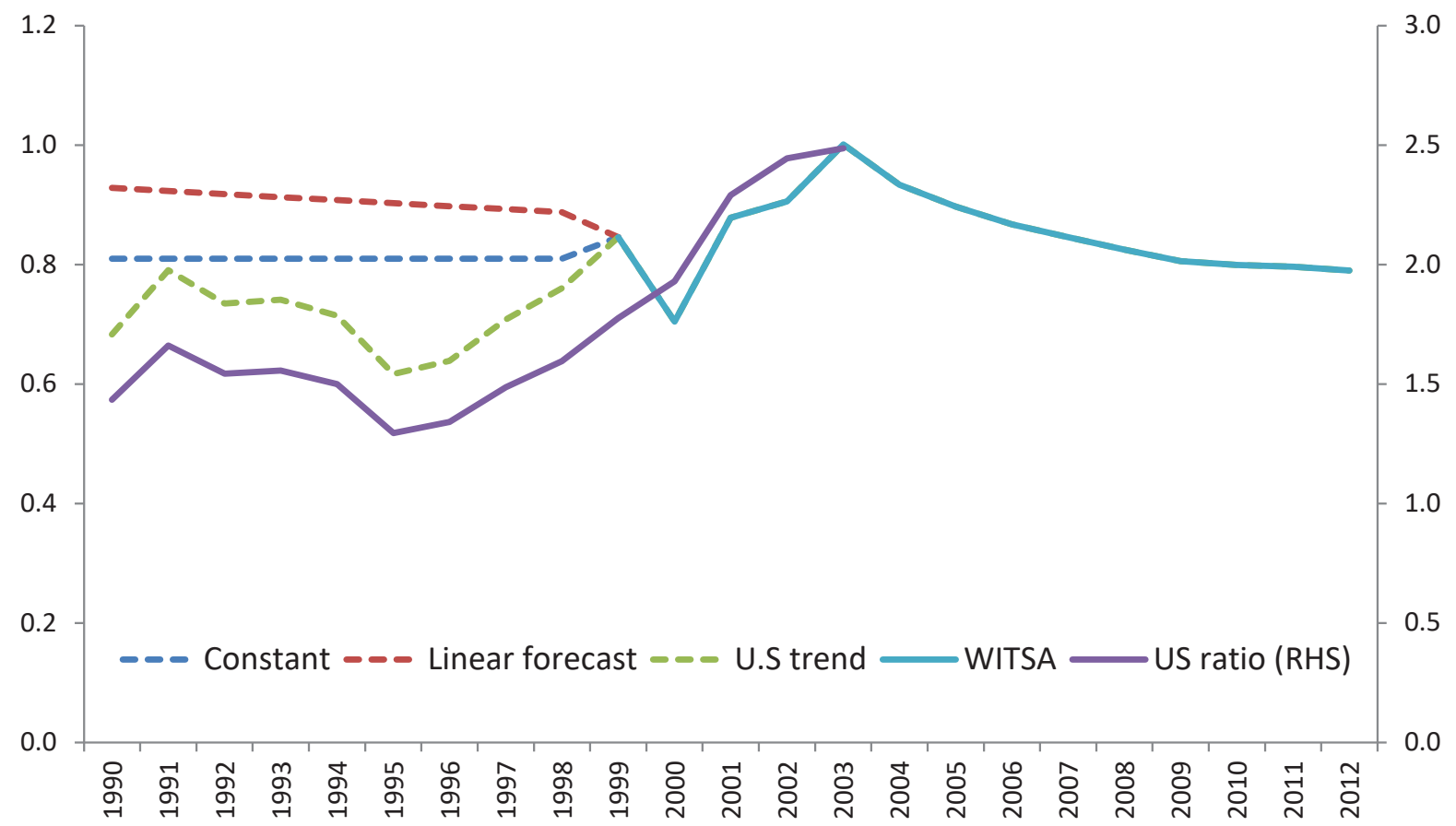

Note: The blue solid line is the ratio of software/hardware spending in non-consumer segments, obtained from WITSA for post 2000 period. This data has been applied to NAS software investment series to estimate hardware investment for the post 2000 period. The U.S ratio (the purple solid line) is plotted on the right hand scale. The blue dotted line assumes a constant software/hardware ratio (based on WITSA) for all years, the red dotted line is a linear trend based on available data and the green dotted line is the trend in the U.S ratio applied to 1999 software/hardware ratio in Indian economy.

Source: Authors' computations, using data from WITSA, EU KLEMS, NAS, and Input-Output Tables.

For years before 1999, we extrapolate software series by applying software/hardware ratio to measured series of hardware investment (measurement of hardware series is discussed below). Here, we use three alternative approaches to derive time series of software/hardware ratio. The first is to keep software/hardware ratio from WITSA in 1999 as constant; the second is to use a linearly forecasted software/hardware ratio from WITSA; and the last and preferred series is to generate a series of software/hardware ratio using the trend in software/hardware ratio in the United States (see Figure 2 for the software/hardware ratio using these three approaches). The U.S data has been obtained from EU KLEMS database. ${ }^{8}$ While this is still a rough assumption, it is better than assuming a constant or linearly growing software/hardware ratio. The U.S, being the

\footnotetext{
${ }^{8}$ We use the 2011 version of the EU KLEMS data, see www.euklems.net.
} 
ICT leader, may provide a realistic picture of the required hardware/software ratio, particularly in the early years. Hence we use the third approach - the trend in U.S software/hardware ratio. ${ }^{9}$

Hardware investment: National Accounts, however, does not provide investment in hardware and communication separately from total machinery investment. In constructing a series of software investment, once hardware data is available, de Vries et al (2010) suggest using the elasticities of hardware to software investment, estimated using a fixed effect panel regression of software on hardware and a set of control variables. We follow a similar approach to derive hardware investment, but not using econometric techniques. We use software/hardware ratio from WITSA ICT spending data (see the blue solid line in Figure 2). While doing this, we exclude consumer spending. This ratio is applied to software series obtained from National Accounts, thus providing us a hardware series for 1999-2011.

For years before 1999, hardware series is obtained using the trends in the hardware investment series arrived at using a commodity flow approach $(\mathrm{CFM})^{10}$. That is the benchmark series for 1999 is extrapolated using the annual changes in the investment series obtained using the CFM. In the CFM approach, total economy investment in hardware and communication equipment can be estimated using the information on the total domestic availability of these goods and its investment component. This requires the use of input-output tables, in combination with NAS and trade statistics. We define the investment in ICT asset $\mathrm{i}$ as:

$$
G F C F_{i, t}=\frac{G F C F_{i, s}^{I O}}{\left(Y_{i, s}^{I O}+I M_{i, s}^{I O}-E X_{i, s}^{I O}\right)}\left(Y_{i, t}+I M_{i, t}-E X_{i, t}\right)
$$

where $\mathrm{GFCF}_{\mathrm{i}, \mathrm{t}}$ is the current gross fixed capital formation, $\mathrm{Y}$ is gross domestic output, IM is imports and EX is exports - all for aggregate economy. Superscript IO refers to input-output tables,

\footnotetext{
${ }^{9}$ Note that the software investment data - be it directly from the NAS, or obtained using hardware/software ratio from WITSA or from the United States - does not capture pirated software used by companies, if any. While the use of such pirated software would indeed contribute to firm's output growth, it will never be reported by firms, and hence is hard to capture.

${ }^{10}$ See de Vries et al (2010) and Timmer and van Ark (2005) for a good description of the commodity flow approach.
} 
i.e. for instance, $I_{i, s}^{I O}$ indicates investment in asset type i (since we consider computer hardware and communication equipment, $\mathrm{i}=1,2$, i.e. hardware and communication equipment) in years (where $\mathrm{s}$ is the benchmark year for IO table) obtained from input-output table. All other variables without the superscript IO are time-series data obtained from the NAS. Following the previous studies, we define industry 30 according to ISIC 3.1 (office equipment and machinery) as computer hardware and industry 32 (radio, TV and communication equipment) as communication equipment. There is no strict concordance between ISIC 3.1 and India's input-output table classification, and therefore, we consider the Indian IO sector office computing and accounting machinery as hardware, communication equipment and electronic equipment including TV as communication equipment (see Table 1). We obtain investment in hardware and communication equipment, along with total domestic output, imports and exports for 6 benchmark years, 1983, 1989, 1993, 1998, 2003 and 2007 from input-output tables published by the CSO. This information is used to compute the first part of equation (1). Then, using time-series data on gross output obtained from National Accounts and exports and imports obtained from UN-Comtrade statistics (see Table 2 for the concordance between Comtrade and ICT assets), we construct a series of hardware investment using equation (1).For years before 1983 (i.e. the first bench mark I-O table), we linearly forecast the domestic availability ratios (see the first part of equation 1), till 1970, so that we can derive a long series of ICT investment that will help us estimate an initial capital stock for an early year (see section 3.3).

Table 1: Input Output Table (IOT) and ICT asset concordance

\begin{tabular}{llrl}
\hline Benchmark years & IOT sectors & $\begin{array}{l}\text { ISIC } \\
\text { industries }\end{array}$ & ICT asset \\
\hline & Office computing machines & 30 & Hardware \\
$1983,1989,1993 \& \&$ & $\begin{array}{l}\text { Electronic } \\
\text { equipment(incl.TV) }\end{array}$ & 30 & $\begin{array}{l}\text { Hardware } \\
\text { Communication }\end{array}$ \\
& Communication equipment & 32 & equipment \\
\hline & Electronic & & \\
& equipment(incl.TV) & 30 & $\begin{array}{l}\text { Hardware } \\
\text { Communication }\end{array}$ \\
& Communication equipment & 32 & equipment \\
\hline
\end{tabular}


As mentioned before, to extrapolate hardware investment series backward we apply the trend in the obtained hardware series to 1999 hardware investment obtained using software/hardware ratio from WITSA applied to software data from NAS. Alternatively, one could directly take the series generated using commodity flow approach for the entire period (i.e. before and after 1999). However, we opted not to do so, because, the industry concordances are not at the maximum precision for IO tables after 2003. Hence, as discussed earlier, we constructed the hardware series for years after 1999 using NAS based software and WITSA based software/hardware ratio. Since the commodity flow approach produces a different estimate for hardware investment in 1999, to keep consistency, we proportionally adjust the series based on commodity flow approach - i.e. by applying the annual changes in commodity flow-based series to the 1999 benchmark estimate of hardware investment.

Table 2: Comtrade and ICT asset concordance

\begin{tabular}{lllll}
\hline HS revision & $\begin{array}{l}\text { HS } \\
\text { code }\end{array}$ & HS industry & $\begin{array}{l}\text { ISIC } \\
\text { industries }\end{array}$ & ICT asset \\
\hline $\begin{array}{l}3(1998 \text { and } \\
\text { after) }\end{array}$ & 714 & $\begin{array}{l}\text { Office machines } \\
\text { Telecommunications } \\
\text { apparatus }\end{array}$ & 30 & $\begin{array}{l}\text { Hardware } \\
\text { Communication } \\
\text { equipment }\end{array}$ \\
\hline & 724 & 32 & Hardware \\
1 (before 1998) & 75 & office machines, adp mach. & 30 & $\begin{array}{l}\text { Communication } \\
\text { equipment }\end{array}$ \\
\hline
\end{tabular}

Communication equipment: For the communication equipment series, we directly take the series generated using the commodity flow approach, using data from the IO table, because the industry description was quite consistent and clear (see Table 1). This way, we have a complete series of ICT investment for the aggregate economy. This approach allows us to generate investment series only for total economy, as an industry break-down is not possible with input-output table.

For all the three assets, investment series for years before 1983 (i.e. the first bench mark I-O table), we linearly forecast the domestic availability ratios (see equation 1), until 1970. The investment estimates obtained from this linearly interpolated series will be used to derive initial capital stock (see section 3). 


\subsubsection{Estimates of aggregate economy ICT investment}

This section presents the estimates of aggregate economy ICT investment - software, hardware and communication - using the methodology discussed in the previous section. First we provide the official software investment data as available from the NAS. It is evident from Figure 3 that the nominal value of investment in software has increased significantly over the period 1999-2000 to 2012-2013. It has increased from ₹ 14,175 crores to ₹ 107,166 crores (nearly 8 times in 14 years). However, its relative size has remained by and large stable. As a percentage of total GFCF, software investment has declined from 2.9 percent in 1999-2000 to 2.3 percent in 2004-2005 (with almost all years seeing a decline), and then had a steady increase until reaching 3.5 percent in 2008-2009. Since 2008, it has been fluctuating, and it hovered around 3.3 percent.

Figure 3: Software investment (₹crores) and its share in total GFCF: Aggregate Economy

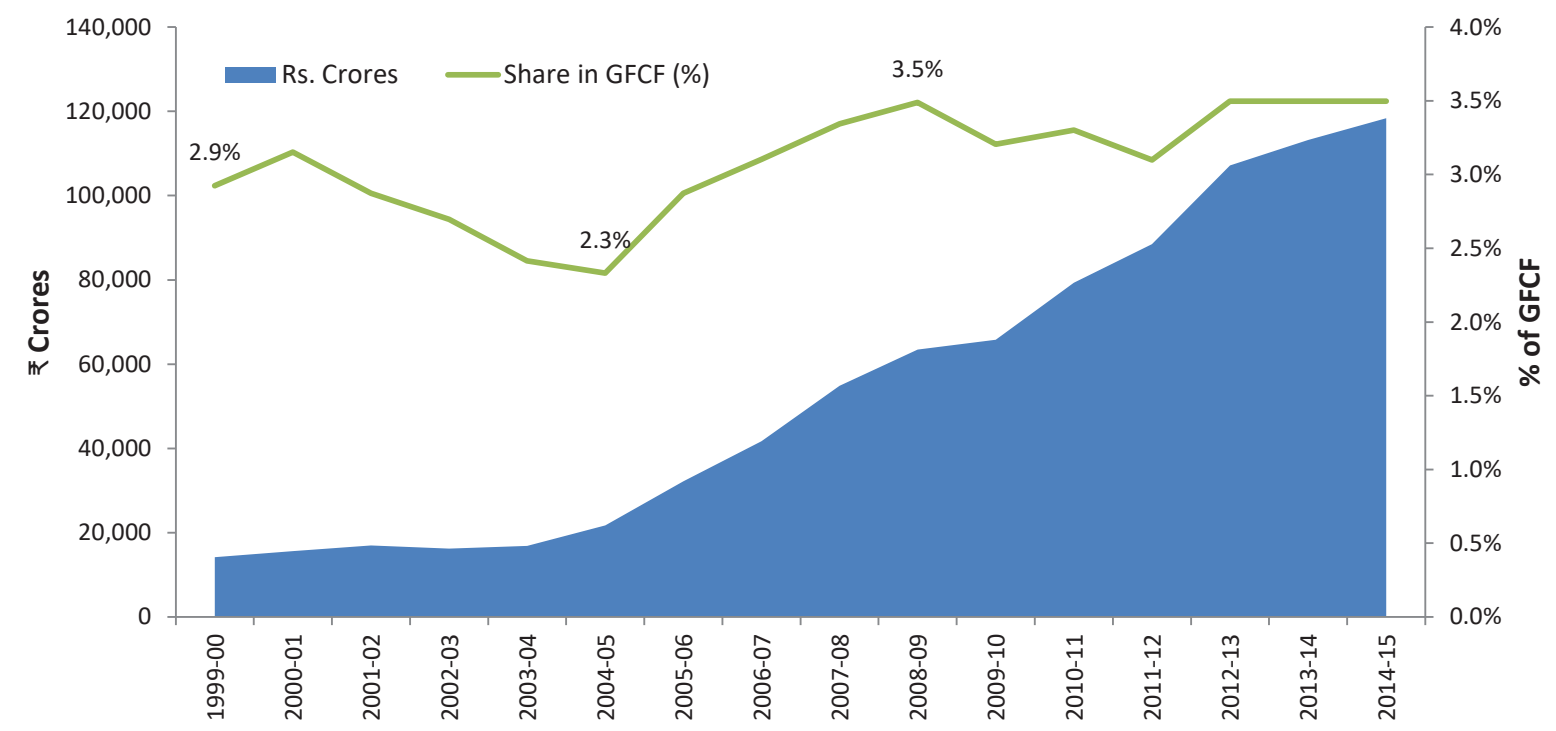

Source: Authors' computations based on National Accounts Statistics.

In Figure 4, we further provide the nominal value of total ICT investment by three asset types - software, hardware and communication equipment - along with the share of total ICT investment in aggregate gross value added. Note that these numbers are obtained by using the methodology described in the previous section, except for the software investment for the period after 1999-2000, which are official NAS series. The figure suggests a significant increase in the total ICT investment over years. It has increased from ₹7,995 crores in 1990-1991 to ₹40,475 crores in 1999-2000 ( 5 times in a decade). There has been a rapid increase after that, reaching₹ 
284,874 crores in $2012-2013$. While the communication investment did see a remarkable increase during 2004-2011 period, also the period of rapid expansion of mobile phones, it started declining since then. It increased from ₹14,267 crores in 2003-2004 to ₹79,362 crores in 2010-2011, but declined in the next two years, reaching ₹50,924 crores in 2012-2013. Hardware constitutes the largest chunk of ICT investment in India and has also been increasing over time; hardware investment increased from ₹23,265 crores in 2004-2005 to ₹130,723 crores in 2012-2013.

\section{Figure 4: ICT investment (₹ crores) and its share in GFCF, Aggregate Economy}

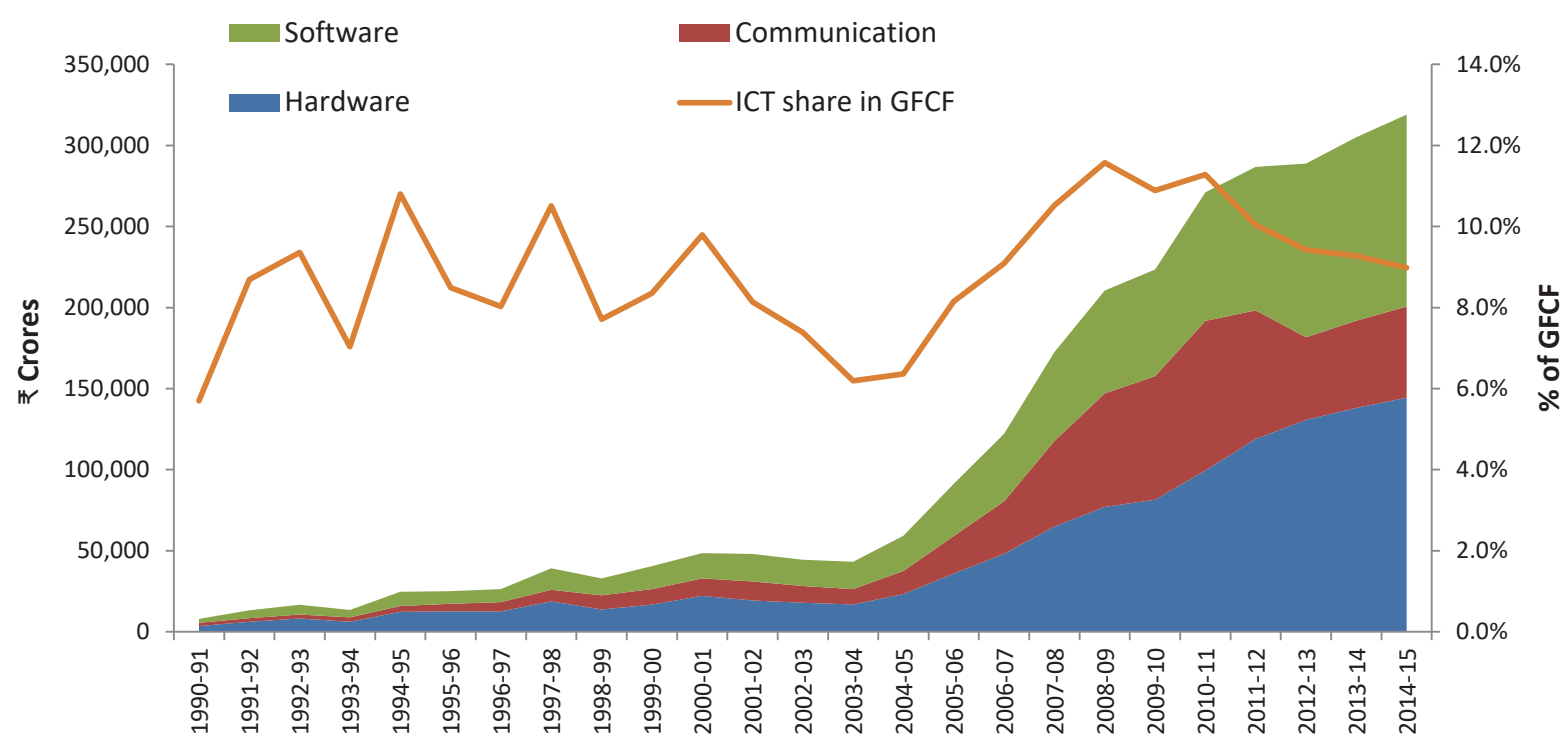

Source: Authors' computations using data from National Accounts Statistics, WITSA and EU KLEMS (see text).

Yet, as is the case with software investment, the relative size of ICT investment in India i.e. ICT investment as a proportion of GFCF has not increased significantly over years. It has been quite volatile during the decade of 1990-2010, ranging from 5.7 percent in 1990-1991 to 10.8 percent in 1994-1995. In 2000-2001, it was 9.8 percent, and then started declining continuously reaching 6.4 percent in 2004-2005. Though it increased since then until 2008-2009, reaching its peak at 11.6 percent, it declined since then, and continued to decline until 2012-2013, reaching 9.3 percent, close to the share it attained in 1992-1993. Thus the relative importance of ICT investment in India has not increased significantly. 
Figure 5: Composition of ICT investment: shares of software, hardware and communication equipment in total ICT investment

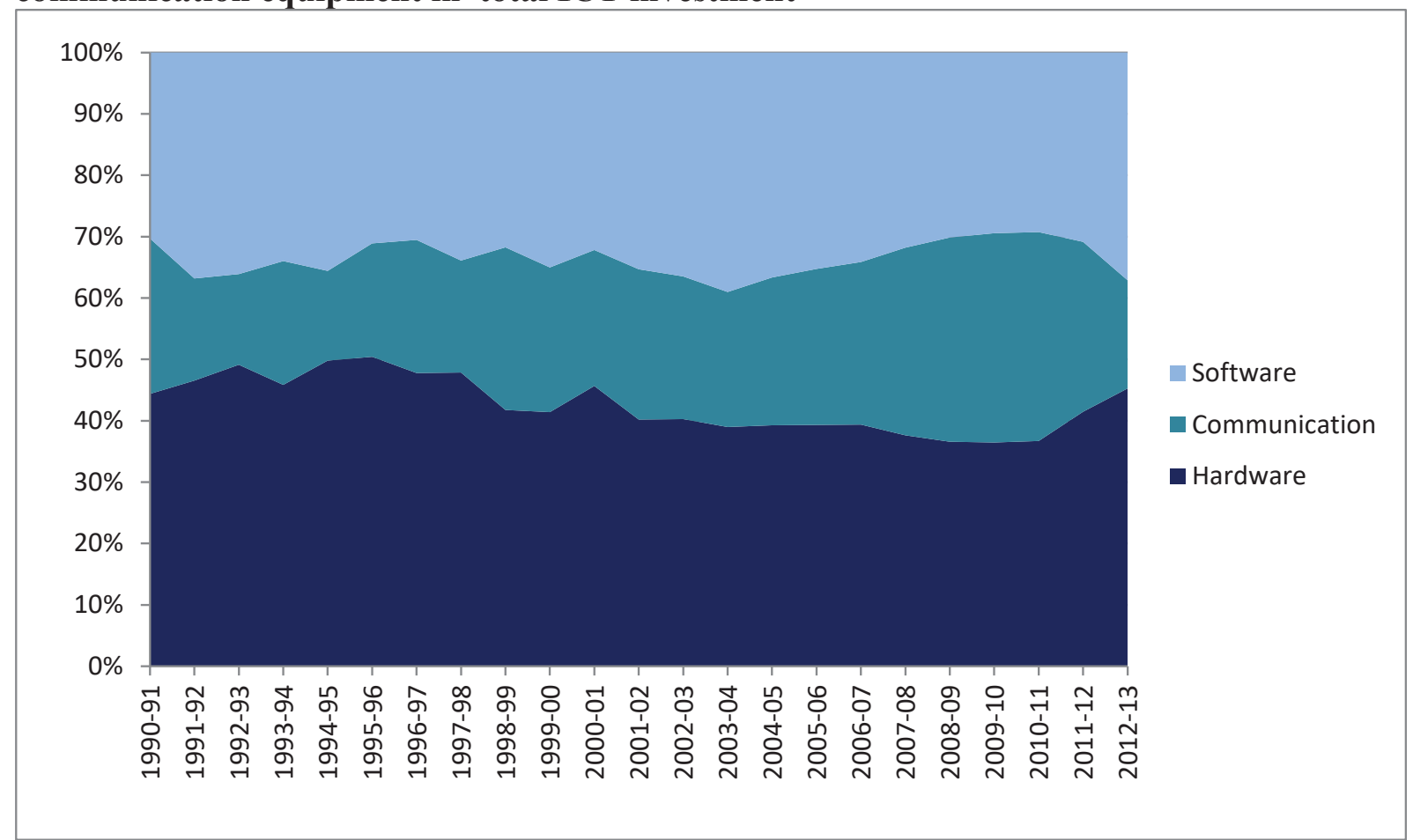

Source: Authors' computations using data from National Accounts Statistics, WITSA and EU KLEMS (see text).

The distribution of ICT investment in terms of software, hardware and communication equipment during 1990-2011, is depicted in Figure 5. Even though India's software sector has been dominating in its ICT exports (see Erumban and Das, 2016), the share of software in aggregate economy ICT investment stayed at about 1/3rd on average since the 1990s. In general, hardware investment dominated, though its share has declined over time. In 1990-1991, communication equipment constituted about $1 / 4$ th of total ICT investment, which declined to less than $1 / 5$ th by the end of the 1990 s. However, it did see an increasing trend since the $1990 \mathrm{~s}$, reaching its peak at 34 percent in 2010-2011, and since then it started declining reaching 18 percent in the last year of the data. On average, during 2008-2012 period, both software and communication equipment accounted for about $30 \%$ percent of total ICT investment each, whereas hardware accounted for nearly 40 percent. 


\subsection{Approach to estimate ICT investment in organized manufacturing}

The construction of ICT series for KLEMS industries of the economy is even more challenging, and therefore, in the current version we attempted this only for the industries in the organized (or formal) segment of manufacturing sector. ASI schedule on fixed assets provides information on 7 individual assets. These are land; building; plant \& machinery; transport equipment; computer equipment including software; pollution control equipment and other assets. The data on computer equipment including software is available only since 1998-1999. This has been taken as the benchmark data for ICT investment in organized manufacturing. ${ }^{11}$ We assume it to consist of the sum of hardware and software investment, and exclude communication equipment. It appears that the communication equipment is still part of plant $\&$ machinery. ${ }^{12}$ We impute GFCF from the fixed assets data using ASI tabulation procedure, i.e.

$$
G F C F_{i, t}^{j_{\_} a s i}=N V F_{i, t}^{c, j_{-} a s i}-N V F_{i, t}^{o, j_{\_} a s i}+D_{i, t}^{j_{-} a s i}-A D R_{i, t}^{j_{-} a s i}
$$

where $\mathrm{GFCF}_{\mathrm{i}, \mathrm{t}}$ is the gross fixed capital formation, $\mathrm{NVF}_{\mathrm{i}, \mathrm{t}}^{\mathrm{c}}$ is the net closing value of fixed assets, $\mathrm{NVF}_{\mathrm{i}, \mathrm{t}}^{\mathrm{o}}$ is the net opening value of fixed assets, $\mathrm{D}_{\mathrm{i}, \mathrm{t}}$ is the depreciation of asset $\mathrm{i}$ during the year, and $\mathrm{ADR}_{\mathrm{i}, \mathrm{t}}$ is the addition due to revaluation; all for ASI industry $\mathrm{j}$, asset $\mathrm{i}(\mathrm{i}=1$ : ICT equipment $)^{13}$ and year t. A numeric example of this approach using the ASI schedule for food and food manufacturing sector is provided in Appendix Table 1.

\subsubsection{Estimates of ICT investment in organized manufacturing industries}

Note that ASI also provides data on actual additions of an asset during the year (also see Appendix Table 1). Instead of re-calculating GFCF using equation (2) one could directly use these series to

\footnotetext{
11 The ASI data on ICT investment has been used by previous studies, some of which are indicated earlier in this paper. For instance, Vashisth (2017) constructs ICT capital stock using ASI firm level data on ICT investment and Joseph and Abraham (2007) make use of the ICT investment data from ASI at 3 digit level in their regression of labor productivity on ICT intensity. Sharma and Singh (2012), also uses investment in ICT from ASI, deflated using machinery and equipment prices. This paper makes a comprehensive attempt to compile the ASI data on ICT and construct measures of capital stock and capital services that are consistent with the approach followed in the India KLEMS database.

${ }^{12}$ Clearly, the ASI data underestimate the extent of ICT use in the organized manufacturing sector, as it only covers the hardware and software investments (also see Vashisht, 2017).

${ }^{13}$ A similar approach is followed to obtain GFCF in all asset types in India KLEMS, while this paper deals only with the ICT.
} 
represent investment in ICT. In figure 6, we provide the estimates of ICT investment in aggregate manufacturing sector, obtained from ASI data using equation (2) along with the actual additions as reported in ASI. Barring some slight deviations, by and large, these two series are quite similar at the aggregate level. However, our preferred series is the measured GFCF series using equation (2), which is also consistent with ASI's own reported GFCF series for total of all assets, as we have observed some notable differences between the two series across industries.

It is obvious from the figure that the absolute level of nominal investment in ICT in the aggregate organized manufacturing sector has increased over time. It increased continuously from about $₹ 650$ crores in 1998-1999 to ₹3,122 crores in 2008-2009. After a decline in 2009-2010, it continued to increase again reaching ₹4,144 crores in 2013-2014.

\section{Figure 6: ICT investment in aggregate organized manufacturing sector (₹ Crores)}

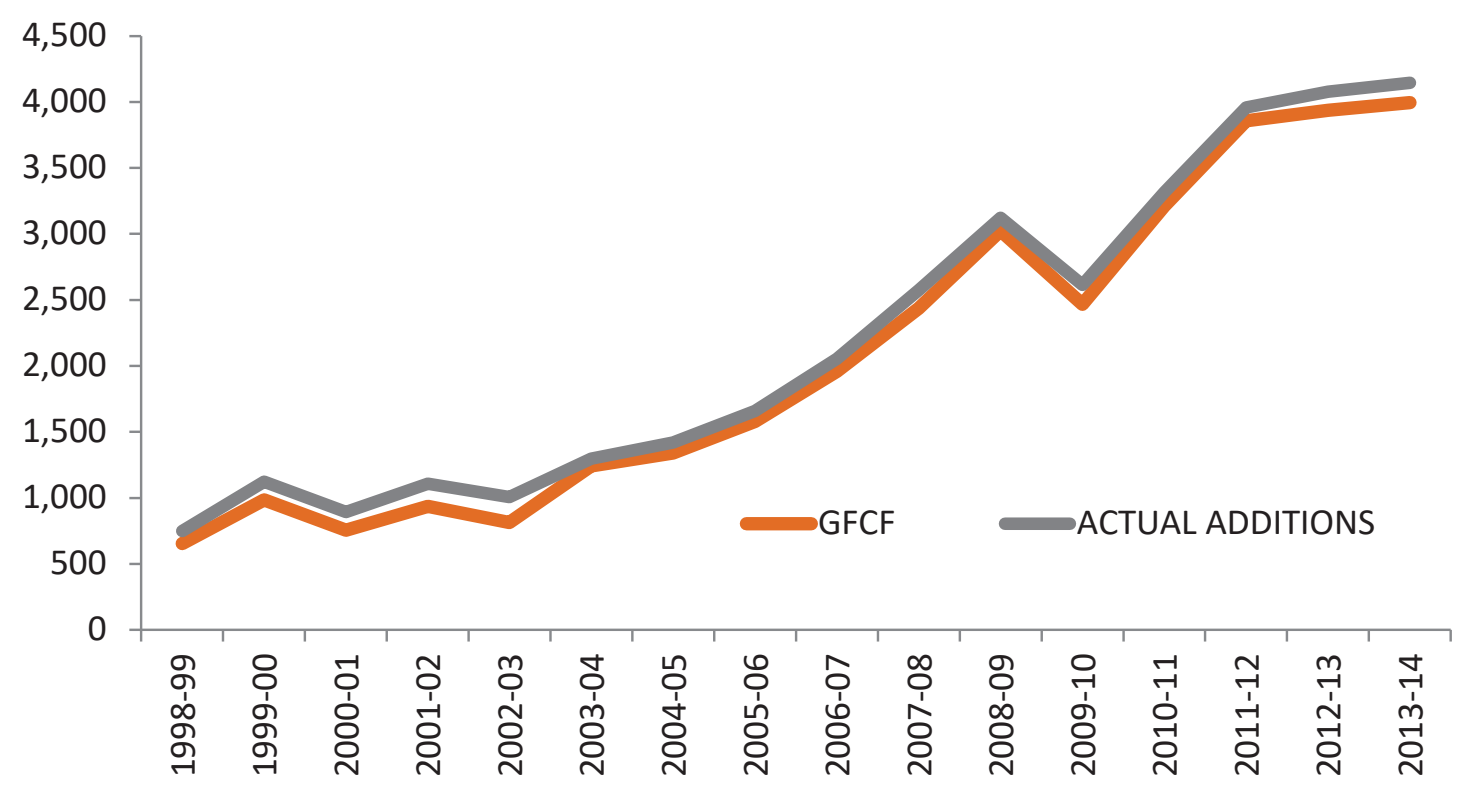

Note: GFCF is Gross fixed capital formation in ICT, obtained using ASI tabulation procedure, i.e. actual additions to ICT assets - deductions during the year. Actual additions are as reported in ASI. The numbers in this chart are consistent with ASI data, but not with national accounts.

Source: Authors' computations using data from Annual Survey of Industries

While the absolute level of ICT investment has increased over time, it has not increased at the same speed as the value added in the sector. The investment to value added ratio has been quite 
volatile, and has in fact declined over years (Figure 7). On average it was 0.5 percent for the entire period 1998-2013, with very little variation, ranging from 0.4 percent in 2000-2001 to 0.6 percent in 2003-2004. In the last year of the data, it was only 0.42 percent of aggregate value added. Obviously, the pace of increases in ICT use in Indian manufacturing has been relatively slower compared to the pace of output expansion. Similar is the case even if we compare the ICT share in total manufacturing investment, suggesting that other types of assets were growing even faster than ICT (Figure 8).

Figure 7: ICT investment/Value added ratio: aggregate organized manufacturing sector (\%)

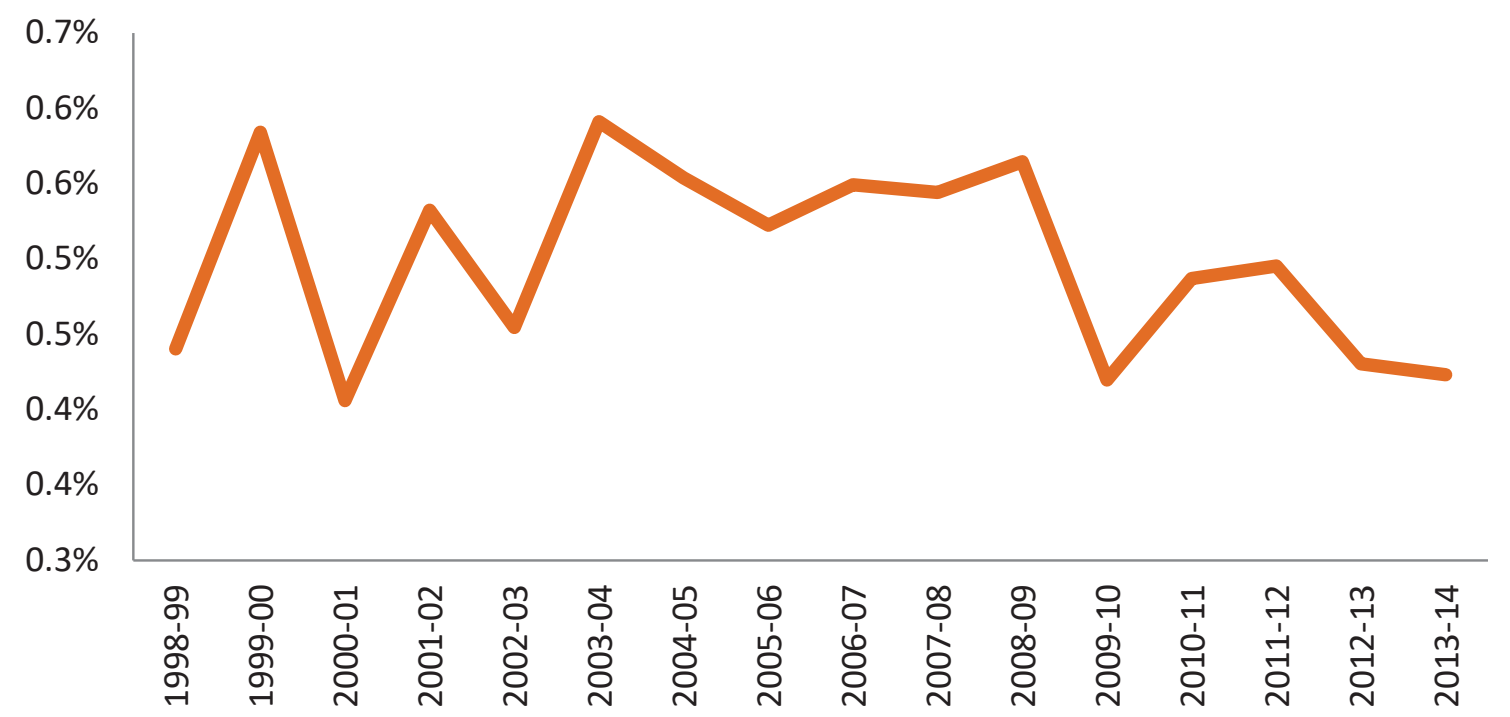

Note: all numbers are consistent with ASI factory sector data, and not necessarily consistent with national accounts data.

Source: Authors' computations using data from Annual Survey of Industries 
Figure 8: Share of ICT investment in total GFCF: aggregate organized manufacturing sector $(\%)$

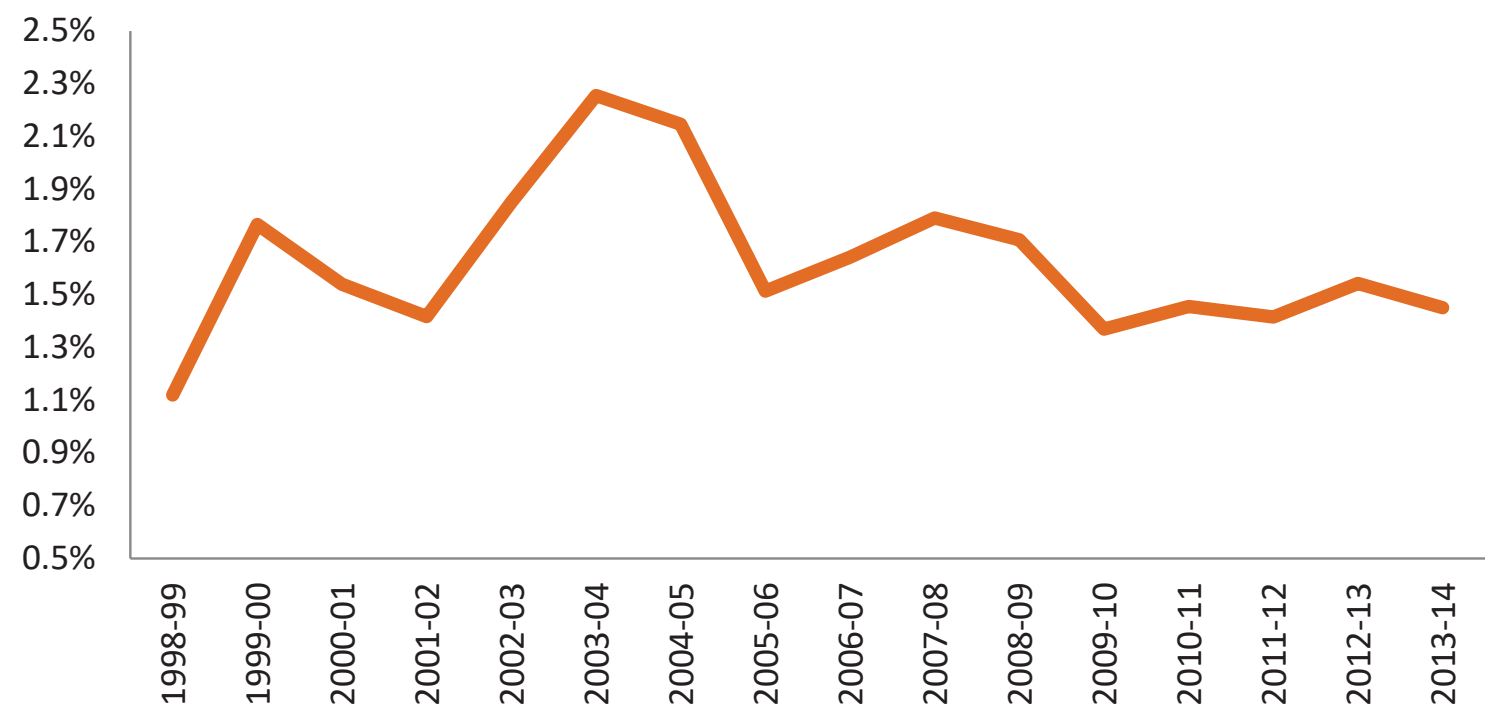

Note: all numbers are consistent with ASI factory sector data, and not necessarily consistent with national accounts data.

Source: Authors' computations using data from Annual Survey of Industries

Estimates of ICT investment are also made for 13 India KLEMS manufacturing sectors (see Appendix 1 for the list of these industries and their abbreviations used in the charts). As one would expect, more technology intensive industries such as electrical \& optical equipment manufacturing, transport equipment and machinery manufacturing industries absorb a major chunk of ICT investment within the organized manufacturing (Figure 9). However, this composition was quite different in the early 1990s, compared to what it is today. In 1993-1994, 22 percent of total ICT investment was in chemicals, 18 percent in textiles and 9 percent in food products. All other industries had less than 5 percent, with wood products being the lowest and non-metallic mineral being the highest at 5 percent. The share of textiles, however, dropped substantially over the years, particularly until the mid-1990s, and is now 6 percent. The share of chemicals also declined by almost 10 percentage point, reaching 13 percent in 2013-2014. The share of machinery, transport and electrical \& optical equipment, on the other hand, increased respectively from 6 percent to 13 percent, from 7 percent to 17 percent and from 8 percent to 18 percent. Thus, together these three industries constitute almost half of the total ICT investment in India's organized manufacturing sector in 2013-2014. 
Figure 9: Industry share in total ICT investment (\%)

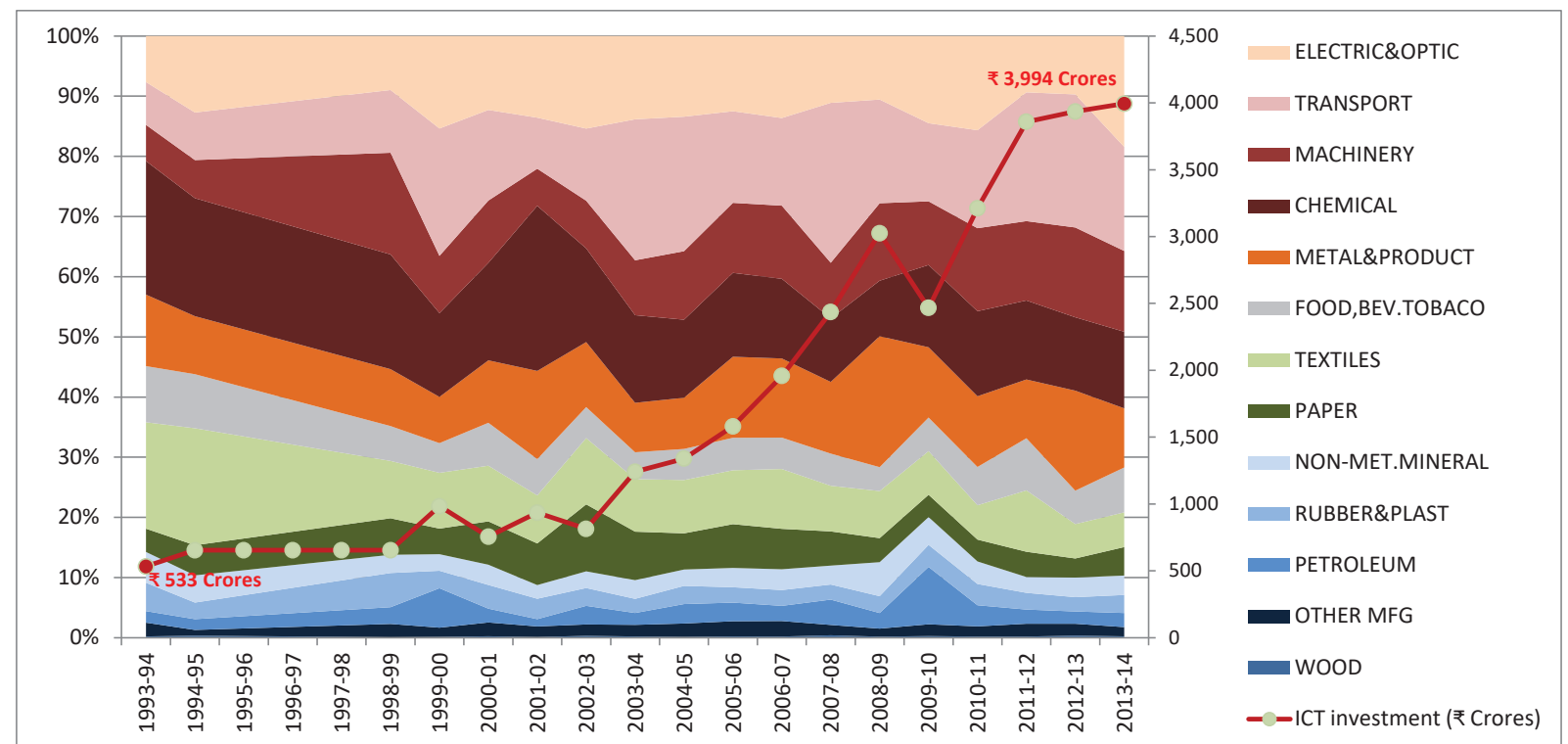

Note: industries are ranked in order of their relative ICT investment size in 2013-2014. All numbers are consistent with ASI factory sector data, and not necessarily consistent with national accounts data.

Source: Authors' computations using data from Annual Survey of Industries

\section{Extending India KLEMS database to include ICT capital}

In India KLEMS database, investment is used as an input to generate capital services that are ultimately used in a growth accounting analysis to estimate input and productivity contribution to output growth. In the case of ICT investment, it requires estimates of ICT capital stock calculation of which requires nominal investment and ICT prices - and its rental prices or user cost. The approach to estimate rental prices are discussed extensively in Erumban (2008) and the specific context of India KLEMS database is described in the India KLEMS data manual. ${ }^{14}$ In this section, we discuss the approach to estimate ICT capital stock and rental prices very briefly, after making the investment data consistent with National Accounts, and thus with existing India KLEMS data.

\footnotetext{
${ }^{14}$ see https://www.rbi.org.in/Scripts/PublicationReportDetails.aspx?UrlPage $=\& I D=855$
} 


\subsection{Consistency with NAS}

In the preceding sections, we developed a series of ICT investment for the aggregate economy and organized manufacturing industries. As indicated earlier the aggregate economy data is fully consistent with NAS. However, the measured ICT investment for the organized manufacturing sector is not consistent with the aggregate economy ICT estimates for two reasons. Firstly, the aggregate economy series is a complete series that consists of investment in software, hardware and communication equipment, while the manufacturing series is only the sum of hardware and software investment (distribution of these two assets are not available), and does not include communication equipment. Secondly, all the series in the aggregate economy is benchmarked to available data on software investment from the NAS, and is thus consistent with NAS. This is not the case with the manufacturing series, which is solely based on ASI data. It is to be noted that there is significant difference between the organized sector capital formation as reported in ASI and the organized manufacturing GFCF data provided in the National Accounts. Therefore, while developing the asset-industry investment series for non - ICT assets (such as buildings, machinery and transport equipment), the India KLEMS has used the asset-industry distribution in the ASI data, keeping the NAS reported GFCF data as the benchmark series. ${ }^{15}$ This way, the India KLEMS data asset-industry investment in non/ICT assets is fully consistent with NAS data.

To ensure the NAS consistency we assume the ICT investment to total GFCF ratio in the organized ASI manufacturing sector to the reported total GFCF data in the organized manufacturing sector in the National Accounts. More specifically:

$$
G F C F_{I C T, t}^{j}=\left[G F C F_{I C T, t}^{j_{a} a s i} / G F C F_{t}^{j_{-} a s i}\right] G F C F_{t}^{j}
$$

where $G F C F_{I C T, t}^{j}$ is the gross fixed capital formation in ICT in industry $\mathrm{j}$ in year $\mathrm{t}$, consistent with National Accounts, GFCF $F_{I C T, t}^{j_{2} a s i}$ is the GFCF in ICT in ASI industry j, GFCF $F_{t}^{j_{a} a s i}$ is the total GFCF (across all assets) in ASI industry $\mathrm{j}$, and $G F C F_{t}^{j}$ is the total GFCF across all assets in industry j, consistent with National Accounts. The obtained total ICT investment using (3) can then

15 See the India KLEMS data manual available at: https://www.rbi.org.in/Scripts/PublicationReportDetails. $\underline{\text { aspx }}$ ?UrlPage $=\& I D=855$ 
be split into software and hardware using the aggregate economy distribution of these two assets, as estimated in section 2.1.1 i.e.

$$
G F C F_{i, t}^{j}=G F C F_{I C T, t}^{j}\left[\frac{G F C F_{i, t}}{G F C F_{S O F T, t}+G F C F_{H A R D, t}}\right]
$$

where $G F C F_{i, t}^{j}$ is the GFCF in asset $\mathrm{i}$ (software and hardware) in industry $\mathrm{j}$ in year $\mathrm{t}, G F C F_{I C T, t}^{j}$ is the GFCF in ICT (sum of software and hardware as obtained in 3) in industry $\mathrm{j}$ in year $\mathrm{t}$ and $G F C F_{i, t}$ is the GFCF in aggregate economy.

The NAS consistent ICT investment series generated using the above approach appears to underestimate the total manufacturing ICT investment. As indicated in the previous section, National Accounts provides data on investment in software by various industries, which includes organized manufacturing as well. The total ICT investment (sum of hardware and software) generated using equation (3) is much lower than the total software investment reported in NAS. This is due to the differences in the way in which National Accounts and ASI compiles their GFCF data - while the former uses an institution approach making use of enterprise level data, the latter is based on establishment approach. This remains a major issue and needs to be tackled in the future revisions of the data. ${ }^{16}$ What is also less evident in the ASI data - which is based on establishment approach - is how it treats ICT assets which are present at the headquarters of a firm and not in the factory surveyed. If these assets get distributed properly among the different factories the firms owns, the difference between establishment and enterprise/institutional approach should be minimal, which is not the case here. A careful look at the distribution of these assets is required to understand this re-distribution issue.

\subsection{ICT prices and depreciation}

Price measurement for ICT assets has been an important research topic in the literature, as the quality of ICT capital goods has been rapidly increasing. The use of a single harmonized deflator across countries was widely advocated and used (Timmer and van Ark, 2005; Schreyer, 2002). We

\footnotetext{
${ }^{16}$ An alternative approach, which is not attempted in the paper yet, is outlined in Appendix 1.
} 
use a harmonization procedure suggested by Schreyer (2002) where the US hedonic deflators ${ }^{17}$ are adjusted for India's domestic inflation rates, i.e.

$$
\Delta \ln P_{I N D}^{I C T}=\Delta \ln P_{I N D}^{n-I C T}+\Delta \ln P_{U S}^{I C T}-\Delta \ln P_{U S}^{n-I C T}
$$

where $\Delta \ln P_{i}^{I C T}$ is the growth rate of ICT prices in country $\mathrm{i}(\mathrm{IND}=$ India, US=United States) and $\Delta \ln P_{i}^{n-I C T}$ is the growth rate of non-ICT prices in country i. Once a NAS consistent ICT series is developed (see the previous section), we use the harmonized ICT deflators to deflate the nominal ICT investments and thus obtain real ICT investment series.

For the depreciation rates, following the standard practice in the literature (see Jorgenson and $\mathrm{Vu}, 2005)$, a 31.5 percent for software and hardware and 11.5 percent for communication equipment are used.

\subsection{Capital stock and the contribution of ICT capital to growth}

India KLEMS uses measures of capital services in its growth accounting analysis (see Das et al, 2016). This requires asset wise capital stock estimates. As is the case with all other assets, we use a standard perpetual inventory method (PIM) to estimate ICT capital stock. Capital stock for a given ICT asset $\mathrm{i}$ can be obtained using the PIM as:

$$
S_{t}^{i}=S_{t-1}^{i} \cdot\left(1-\delta^{i}\right)+I_{t}^{i}
$$

where $\boldsymbol{S}_{\boldsymbol{t}}^{\boldsymbol{i}}=$ capital stock in ICT asset i in year t, $\boldsymbol{\delta}^{\boldsymbol{i}}=$ geometric depreciation rate of ICT asset $\mathrm{i}$ and $\boldsymbol{I}_{\boldsymbol{t}}^{\boldsymbol{i}}=$ real investment in ICT asset i (deflated using the harmonized price deflators). This requires an initial capital stock. Given that investing in ICT is relatively a new development, it is ideal to assume a zero initial stock for an early year, say 1970. Due to high depreciation rates of ICT assets, this assumption does not affect the growth rates for later years. As mentioned in section 2, we have extended the ICT investment series for the aggregate economy until 1970, using a linearly

\footnotetext{
17 Our harmonized price deflators are based on the U.S hedonic prices, which are constructed using a hedonic regression where prices of ICT equipment regressed on several characteristics, such as for instance processor speed, hardware size, memory etc.
} 
extrapolated domestic availability ratio and the time-series of domestic availability of ICT assets, and these series can be used to obtain an initial stock for 1970 .

For the manufacturing sector, given the short time-series we have, we approximated an initial capital stock using capital stock to investment ratio in the aggregate economy for 1992-93. Given that the initial capital stock is estimated in a crude way, the results on growth contribution will be reliable only after a few years, after allowing for the depreciation of a major part of first available investment data. Fortunately, given the high rate of depreciation, the effect of initial capital on estimated growth rate will vanish quite quickly.

The contribution of ICT capital to value added growth is obtained as the product of ICT capital compensation share in nominal value added and the growth rate of ICT capital stock. ${ }^{18}$ The compensation share of ICT capital is estimated by multiplying rental price of ICT capital with ICT capital stock, with the rental price being estimated using depreciation rate, an assumed external rate of return and investment prices, as spelled out in Das et al $(2016)^{19}$.

\section{Contribution of ICT to economic growth - aggregate economy and organized manufacturing}

In figure 10 we provide the contribution of ICT to value added growth in the aggregate economy since 1996 till 2011. The whole period is divided into three sub-periods, 1996-2000, 2001-2005 and 2007-2011. On the right hand side of the figure we have the value added growth, and on the left hand side the contribution of ICT capital to value added growth. Clearly, the value added growth has increased over years, however, the contribution of ICT capital has not increased by a similar magnitude. In the first period, out of more than 6 percent value added growth, only less than 1 percentage point was due to ICT use (i.e. about 15 percent of total growth). This has declined to 0.6 percentage points in the second period, even when value added growth increased to more than 6.5 percent, thus lowering the relative contribution to less than 10 percent of value added growth. In the last period, however, there has been some improvement. When the value added

\footnotetext{
${ }^{18}$ ICT income share is obtained using ICT rental prices, which are computed using internal rate of return, depreciation rate and ICT investment deflators (see Erumban and Das, 2016 and Erumban 2008 for detailed discussion on the calculation of rental prices).

${ }^{19}$ Also see the India KLEMS data manual, available at: https://www.rbi.org.in/Scripts/PublicationReportDetails. aspx? UrlPage $=\& \mathrm{ID}=855$
} 
growth increased to 8.3 percent, contribution of ICT increased to 1.4 percent, thus regaining its relative contribution to about 16 percent.

A comparison of our results with that of the Conference Board Total Economy Database (TED) suggests a similar trend in the contribution of ICT capital. According to the TED data, the relative contributions of ICT (relative to GDP growth) has declined from 18 percent during 1996-2000 to 9 percent during 2001-2005 and then increased to just above $1 / 5^{\text {th }}$ of the GDP growth. ${ }^{20}$

\section{Figure 10: Contribution of ICT (hardware, software and communication equipment) capital to value added growth, Aggregate Economy}

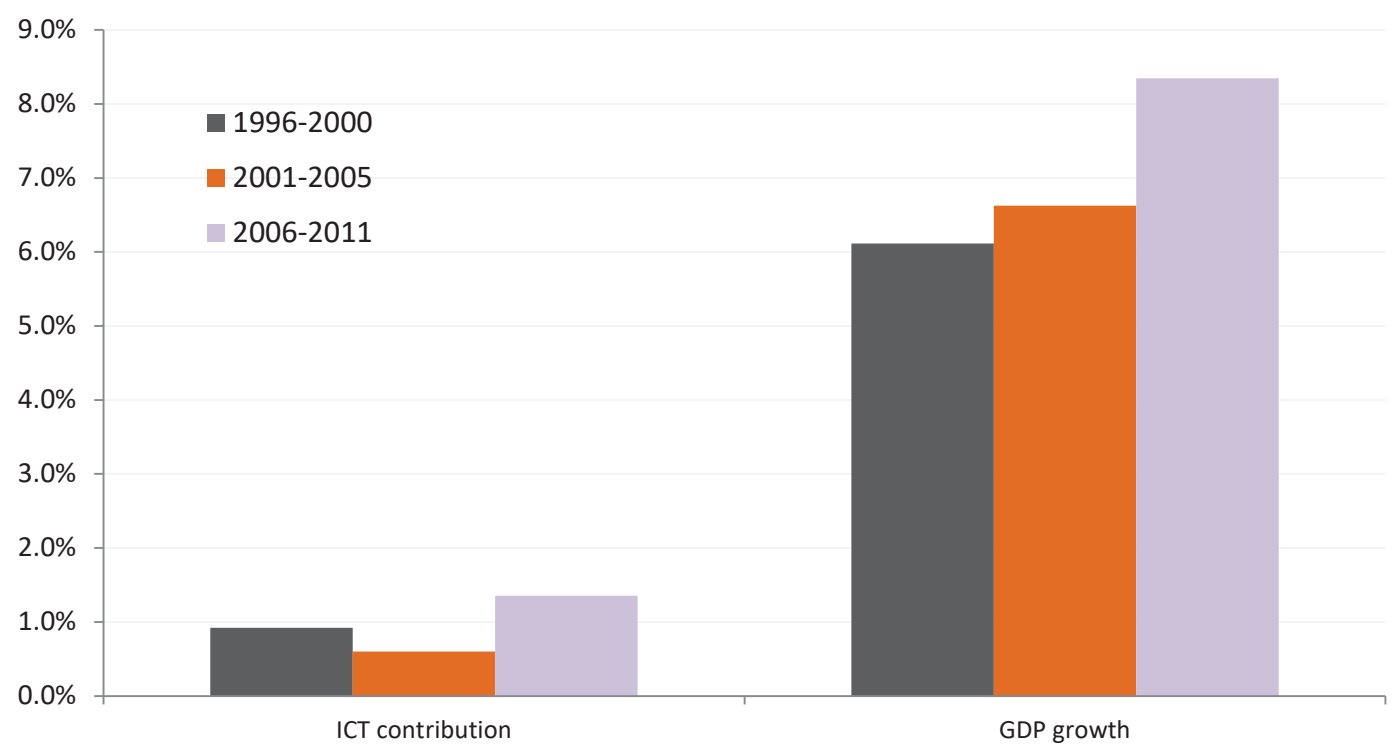

Source: Authors' computations using data from NAS.

\footnotetext{
${ }^{20}$ Note that there are some differences between TED estimates and our estimates. The first is that in the TED output and GFCF data for the aggregate are converted to calendar year (using quarterly data) and the asset distribution is applied to those annual data to obtain asset wise data. Secondly, the price deflator for ICT used in the TED are based on a new alternative measures developed by Byrne and Corrado (2016), while the hedonic deflators used in our paper is based on official BEA ICT hedonics for U.S. Finally, the TED numbers are relative to 'GDP', whereas ours is relative to gross value added.
} 
Figure 11: Contributions of ICT (hardware, software and communication equipment) and non-ICT capital to GDP growth, Aggregate Economy

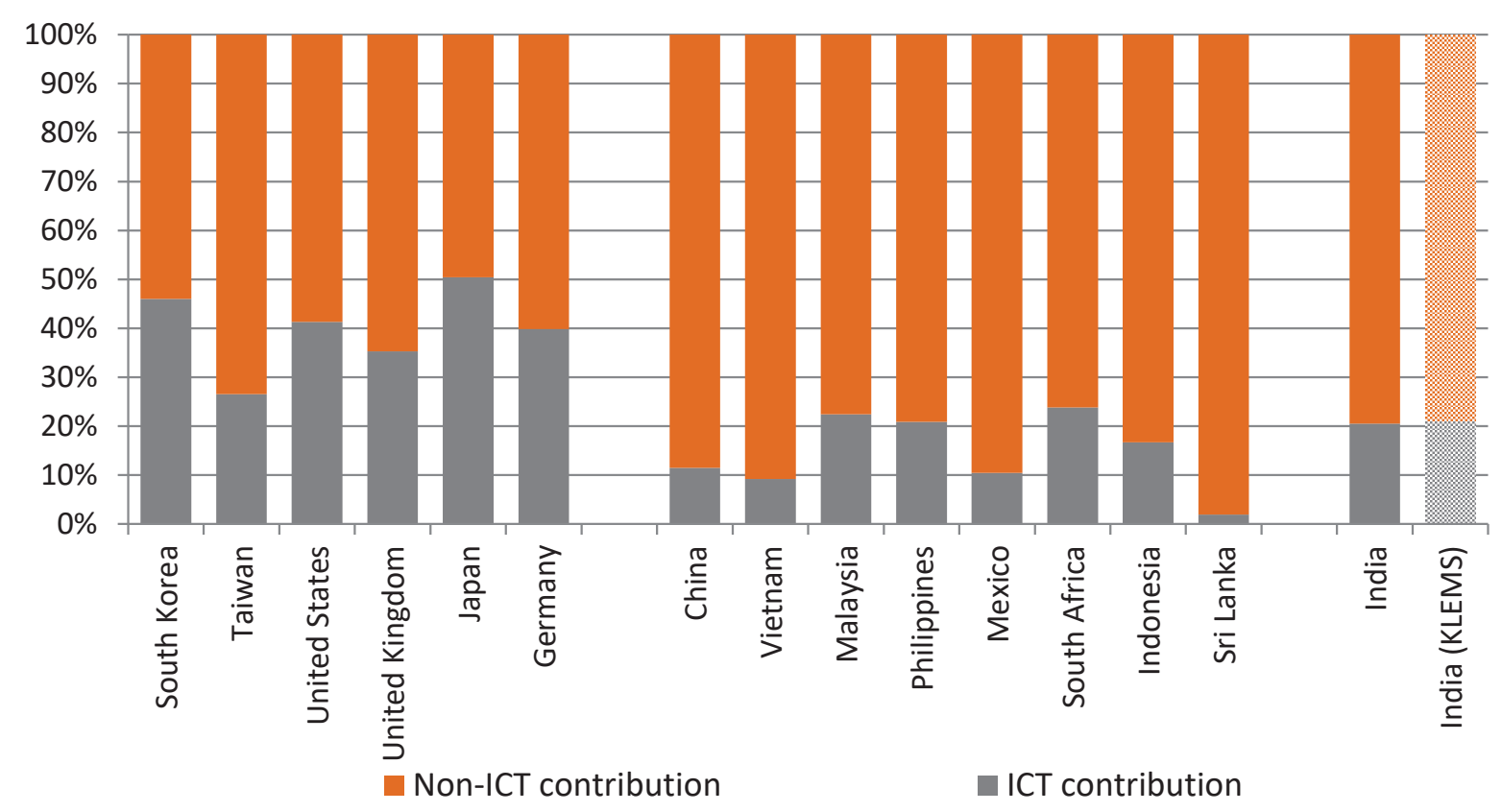

Source: The Conference Board Total Economy Database, May 2016 and authors' computations using data from NAS.

In Figure 11 we further compare our results for India with several other countries - both mature and emerging market economies - using the TED data. Interestingly, India compares well with other developing countries in regard to the contribution of ICT capital to growth. If we consider the contributions of ICT capital and non-ICT capital to economic growth and assess the relative importance of these two, India seem to be doing well at the aggregate level. However, compared to mature economies, where the ICT revolution started even earlier than in most emerging market economies, the relative importance of ICT in India and other emerging market economies is still low. ${ }^{21}$

Given that we do not have a long series of ICT data in the database, it is appropriate to focus on the results for most recent years, after allowing for depreciated stock in the early years. Therefore, we provide the results on the contribution of ICT capital to value added growth in

\footnotetext{
21 In an earlier study, Papaioannou and Dimelis (2007) suggest strong ICT effects on economic growth, with the effects being larger on developed economies than on developing economies.
} 
registered manufacturing only for 2001-2011 period. On average the contribution of ICT capital (excluding telecommunication equipment) in registered manufacturing sector is about 0.2 percentage point over the period 2001-2011 (Figure 12). There has been only a marginal increase from 2001-2005period to 2006-2011 period. Despite several industries witnessing improvement in ICT contribution, the drop in two major industries - paper, printing and publishing industry, and electrical and optical equipment manufacturing industries - has driven down the aggregate contribution. These two industries had the highest ICT contribution in the first period. In the case of paper and products the faster growth of ICT might be due to the large presence of publishing industry (including media reproduction and newspaper), the share of which in the total value added still relatively small, but is increasing. Electrical and optical equipment industry is an obvious candidate to have higher ICT investment, as it is globally an ICT intensive sector. Machinery and transport equipment sectors were the other two sectors with notable ICT contribution to value added growth. While in both these sectors the contribution of ICT remained by and large the same, electrical and optical equipment sector and paper and publishing sector both witnessed significant declines in their ICT contribution.

Clearly there is significant variation across industries in ICT use. And overall there has been some improvement - 11 out of 13 industries have witnessed an increased, albeit small in magnitude, in the absolute contribution of ICT to growth - leading to minor increase in the contribution of ICT to growth in organized manufacturing. Yet, the performance of registered manufacturing, in terms of ICT use, seem to be quite negligible, when compared to the aggregate economy, implicitly indicating that perhaps it is the services sector of the economy that has been using the ICT more intensely. This, however, require further extension of the data to include service sector. 
Figure 12: Contribution of ICT (hardware and software only) capital to value added growth, Registered Manufacturing Sector
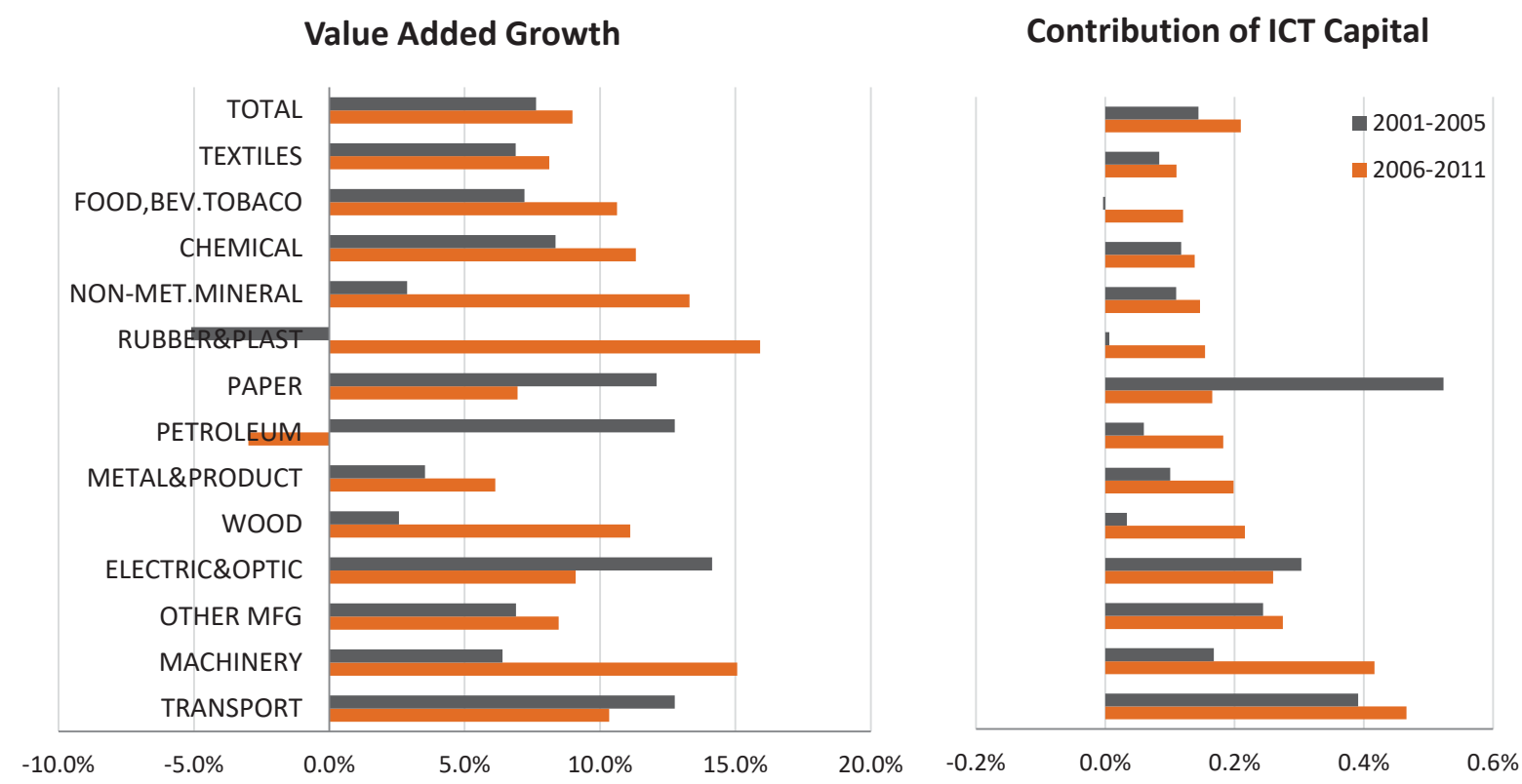

Note: The results in this chart are made consistent with national accounts data (see text). Detailed industry names are provided in Appendix Table 2.

Source: Authors' computations using data from ASI and NAS.

\section{Main findings}

This paper made a first attempt to estimate ICT investment in Indian economy - both at aggregate level and for individual manufacturing industries in the organized segment. Our estimates seem to suggest an increase in the nominal value of investment in software, hardware and communication equipment in the aggregate economy over the last 2 decades. However, as a share in GDP, it has in fact declined. A similar pattern is observed in the case of aggregate organized manufacturing sector as well, where we see the total ICT investment (sum of hardware and software) increases over years, while its share in value added and total investment has been quite volatile with little increase.

Subsequently, the paper also provided some preliminary results on the contribution of ICT capital to value added growth in aggregate economy, and 13 India KLEMS manufacturing industries, in the organized segment of the economy. The results suggests that while there is some marginal increase in the ICT use and its contribution to growth in Indian manufacturing, the sector still lags quite behind, particularly when compared to the aggregate economy. Obviously, there is 
more potential for exploiting the benefits of ICT in Indian economy, particularly in the manufacturing sector, which can help Indian firms to improve their competitiveness.

While many factors play a role here in making Indian industries' low ICT use, an important one is the role of complementary investment. To embrace ICT and digital technology fully into the production process, firms also need to invest in several complementary assets, including human capital, training, intangible assets, and organizational restructuring. For instance, a firm level study by Bresnahan et al. (1999) suggests that the declines in ICT price lead to increased use of a complementary system. They observe a complementarity between skilled workers and ICT and suggest the importance of complementary organizational investment in raising the effects of ICT

on labor demand. Such complementary investments, particularly those related to significant internal re-organization within business organizations are often a slow process and is often a function of culture as well. Therefore, even if the investment is made in information and communication assets, translating it into productivity requires such complementary investment. In the case of India, the low level of investment in ICT might itself is partly due to the low pace of such complementary assets. Even the invested assets may not be fully utilized and translated into growth, if not accompanied by required human capital and organizational investment - an aspect that cannot be captured by our growth accounting approach.The results in this paper are preliminary, and require further scrutiny and revisions. Moreover, there is still substantial room for improving these estimates, as we are bound to make strong assumptions in the calculation procedure.

\section{Way Forward}

The estimates presented in this paper may be considered as preliminary, as it involves significant amount of assumptions and imputations. In the process of constructing these estimates, we realize the estimates could be improved using more available information, and these will be explored in the subsequent works. For instance, instead of using trade data from UN Comtrade (see Section 2.1), we could exploit detailed data from WITS or DGCSI. Also, given that most of the ICT investment goods are likely to be produced in the formal/organized segment of the manufacturing sector, instead of relying on NAS output data in constructing the domestic availability (see section 2.1), one may use detailed output data from ASI. 
Since the commodity flow approach provides estimates of hardware and communication, it is logical to use this series on hardware for the entire period. However, the current version, we do not use the hardware estimates obtained from CFM for years after 1999, because of the inaccuracy in concordance between industry classification in input-output tables and our ICT definition. Future work may explore further possibilities of improving the commodity flow approach and rely fully on the IO based hardware series.

Also for imputing missing data on hardware and software, we relied on hardware/software ratio from WITSA and from the United States. An alternative option, which may be explored in the future versions, is to rely on the firm level information on gross fixed assets in software and hardware from CMIE's Prowess data.

Finally, exploiting other available sources such as the Prowess and NSSO manufacturing surveys, estimates of ICT investment may be generated for other KLEMS industries, which include unorganized manufacturing and services industries. This would account for further heterogeneity across industries within Indian economy. Indeed, such industry level analysis is insightful in obtaining a broad perspective on ICT's contribution to growth and is far better than aggregate analysis. Yet, one should not overlook the possibility that it can still mask several minute dynamics at the firm level. This is of particular importance when it comes to ICT's impact in a developing country like India, due to significant heterogeneity across firms in terms of their ICT use and exposure - depending upon for instance their export intensity, their target consumers etc. In the future work, one should complement the industry analysis with detailed firm-level studies. While this paper is our first attempt to build an ICT investment series, and to quantify its contribution to growth in Indian industries, using a standard growth accounting approach, it does not end our quest to answer the question of ICT's role in India's growth. In the future, we aim to continue analyzing the role of ICT using more comprehensive econometric tools, which would help us understand the intensity of ICT's effects more precisely. 


\section{Bibliography}

Arora, A., Athreye, S., 2002.The software industry and India's economic development, Information Economics and Policy, 14(2), 253-273.

Byrne, D and C. Corrado., 2016. ICT Asset Prices: Marshaling Evidence into New Measures, The Conference Board Economics Program Working Paper \#16-06

Baldwin, R., 2016. The Great Convergence, Harvard University Press.

Bresnahan, T.F., E. Brynjolfsson., and L. M. Hitt., 2002. Information Technology, Workplace Organization, and the Demand for Skilled Labor:Firm-Level Evidence, The Quarterly Journal of Economics, 117 (1), 339-376

Central Statistical Organization, The Government of India, Annual Survey of Industries, various issues Central Statistical Organization, The Government of India, National Accounts Statistics, various issues

Central Statistical Organization., 2010. Value addition \& employment generation in the ICT sector in India, New Delhi, Ministry of Statistics and Planning, Government of India.

Commander, S., Harrison, R., Menezes-Filho, N., 2011. ICT and productivity in developing countries: New firm-level evidence from Brazil and India, The Review of Economics and Statistics, 93 (2), 528-541.

Das, D.K., A.A. Erumban., S. Aggarwal., S. Sengupta., 2016. Productivity growth in India under different Policy Regimes, in Jorgenson D., Timmer, M.P., Fukao, K. (Eds), The World Economy: Growth or Stagnation?, Cambridge University Press.

De Vries, G.J., Mulder, N., Dal Borgo, M., Hofman, A. A., 2010. ICT investment in Latin America: Does it matter for economic growth?", in Cimoli, M., Hofman, A.A., Mulder, N. (Eds), Innovation and economic development: The impact of information and communication technologies in Latin America, Edward Elgar, Northampton, Massachusetts.

Erumban, A.A, and Das, D. K., 2016. Information and communication technology and economic growth in India, Telecommunications Policy, 40 (5), 412-431

Erumban, A, A., 2008. Rental prices, rates of return, capital aggregation and productivity: Evidence from EU and US, CESifo Economic Studies, 3 (54), 499-533.

Inklaar, R., Timmer, M.P., van Ark, B., 2008. Market services productivity across Europe and the US, Economic Policy, 25(33), 139-194.

Jorgenson, D.W., 2001. Information technology and the US economy, American Economic Review, 91(1), $1-32$.

Jorgenson, D.W., Ho, M.S., Stiroh, K.J., 2005. Information Technology and the American Growth Resurgence, The MIT Press, Cambridge, Mass.

Jorgenson, D.W., Vu, K., 2005. Information technology and the world economy, Scandinavian Journal of Economics, 107(4), 631-650.

Joseph, K. J., V. Abraham., 2007. Information Technology and Productivity: Evidence from India's Manufacturing Sector, Working Paper 389, Centre for Development Studies, Trivandrum, Kerala, India.

Kite, G., 2012. The impact of information technology outsourcing on productivity and output: New evidence from India, International Conference On Applied Economics, 239 - 248

Kite, G., 2013. The role of information technology outsourcing on output, productivity and technical efficiency: Evidence from Indian firms, Journal of European Economy, 12 (3), 260-285 
Mitra, A., Sharma, C., Veganzones-Varoudakis, M., 2016. Infrastructure, ICT and firms's productivity and efficiency: An application to the Indian Manufacturing, in F. De Beule and K. Narayanan (eds.), Globalization of Indian Industries, India Studies in Business and Economics, Springer Science+Business Media Singapore.Navyashree G. R., S. Bhat., 2016. ICT Investments and Growth of Small and Medium Firms: A Study of Food Processing Industry in India, Paper presented at the Forum for Global Knowledge Sharing, Indian Institute of Technology, Madras, http://fgks.in/images/pdf/conf/2016/Navyashree.pdf

Papaioannou, S.K., and S.P. Dimelis., 2007. Information technology as a factor of economic development: Evidence from developed and developing countries, Economics of Innovation and New Technology,16(3), 179-194

Saith, A., M Vijayabaskar., 2005. ICTs and Indian Economic Development: Economy, Work, Regulation, SAGE Publications Pvt. Ltd

Schreyer, P., 2002. Computer price indices and international growth comparisons, Review of Income and Wealth, 48(1), 15-31.

Sharma, S., N. Singh., 2012. Information Technology and Productivity in Indian Manufacturing, India policy forum, 2012-13, 189-238

The Conference Board, 2016. The Conference Board Total Economy Database ${ }^{\mathrm{TM}}$, May 2016, https://www.conference-board.org/data/economydatabase/

Timmer M., van Ark, B., 2005. Does information and communication technology drive EU-US productivity growth differentials?, Oxford Economic Papers, 57(4), 693-716.

van Ark, B., Gupta, A., Erumban, A.A., 2011. Measuring the contribution of ICT to economic growth, in van Ark, B. (Eds), The Linked World: How ICT Is Transforming Societies, Cultures, and Economies, Ariel and FundaciónTelefónica, Madrid.

van Ark, B., Inklaar, R., McGuckin, R.H., 2003. Changing gear: Productivity, ICT and service Industries in Europe and the United States, in Christensen, J.F., Maskell, P. (Eds.), The Industrial Dynamics of the New Digital Economy, Edward Elgar, London.

Vashisht., 2017. Destruction or Polarization: Estimating the Impact of Technology on Jobs in Indian Manufacturing, ICRIER working paper 334 


\section{Appendix 1}

Another way of estimating NAS consistent ICT series for organized manufacturing is to consider the reported NAS software data as the benchmark, and obtain hardware as a residual. That is, for years for which the NAS software data is available (1998 onwards), consider the NAS data as the benchmark estimates for the aggregate registered manufacturing. Hardware investment for the first year of the data for which the software data is available in NAS can then be obtained using the aggregate economy software/hardware ratio. This way we can obtain the total investment in ICT for the first year as the sum of hardware and software. For all other years the total ICT investment may be obtained by applying the growth rate of total ICT investment in ASI. The hardware series can then be calculated as the residual after subtracting the NAS reported software investment from this total. More formally,

$$
G F C F_{H A R D, 1998}^{J}=\frac{G F C F_{S O F T, 1998}^{J}}{\emptyset_{1998}}
$$

where $G F C F_{H A R D, 1998}^{J}$ is the GFCF in hardware in 1998 in total registered manufacturing sector, $G_{\text {GCF }}^{J}{ }_{S O F, 1998}$ is the total registered manufacturing investment in software in 1998 and $\emptyset_{1998}$ is the software to hardware ratio for the aggregate economy in 1998. Subsequently, total ICT investment in total registered manufacturing sector may be obtained as:

$$
G F C F_{I C T, 1998}^{J}=G F C F_{S O F T, 1998}^{J}+G F C F_{H A R D, 1998}^{J}
$$

And for $\mathrm{t}>1998$

$$
G F C F_{I C T, t}^{J}=G F C F_{I C T, t-1}^{J}\left[\frac{G F C F_{I C T, t}^{J \_a s i}}{G F C F_{I C T, t-1}^{J-a s i}}\right]
$$

Since the software data is taken as such from National Accounts, the hardware can be obtained as a residual:

$$
G F C F_{H A R D, t}^{J}=G F C F_{I C T, t}^{J}-G F C F_{S O F T, t}^{J}
$$

While this is still a less perfect approach, the positive side of it is that it ensures complete consistency with NAS reported software data and the trend in aggregate ICT investment in ASI. 
Appendix Table1: ASI fixed assets schedule - food and food manufacturing (ISIC 15) in 2007-2008 (all values in Rs. Lakhs)

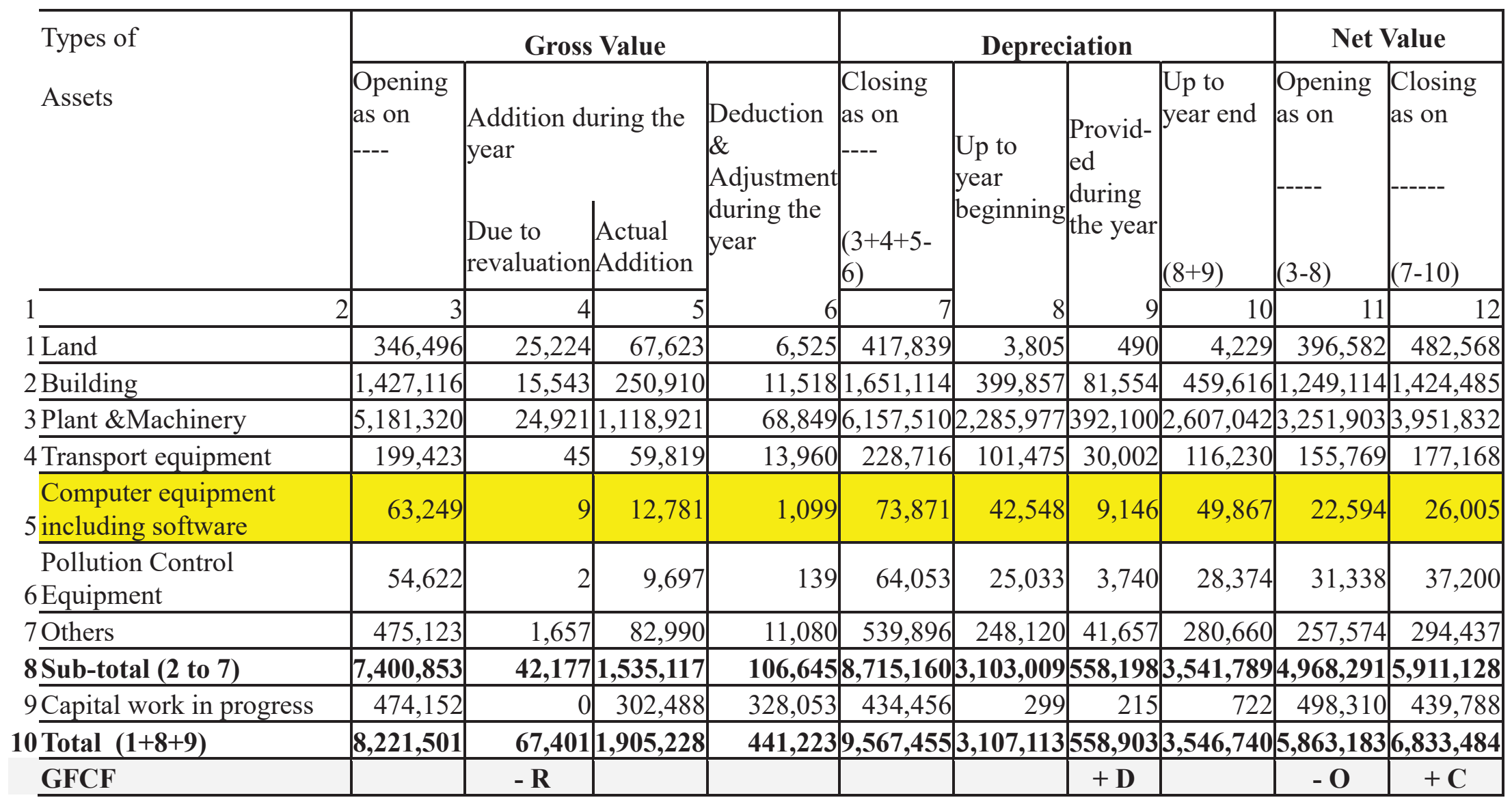

Note: Estimated GFCF in ICT $(12-11+9-4)=26,005-22,594+9,146-9=12,548$, and the estimated total GFCF in food and food manufacturing sector $=1,461,803$. The reported ASI factory sector GFCF is $1,461,802$. 
Appendix Table 2: List of India KLEMS manufacturing industries

\begin{tabular}{|c|c|c|c|}
\hline Sl. No. & ISIC & s India KLEMS industries & Abbreviations \\
\hline 1 & $15 \mathrm{t} 16$ & Food, beverages and tobacco & FOOD,BEV.TOBACO \\
\hline 2 & $17 \mathrm{t} 19$ & Textiles, textile, leather and footwear & TEXTILES \\
\hline 3 & 20 & Wood and of wood and cork & WOOD \\
\hline 4 & $21 t 22$ & Pulp, paper, paper, printing and publishing & PAPER \\
\hline 5 & 523 & Coke, refined petroleum and nuclear fuel & PETROLEUM \\
\hline 6 & 524 & Chemicals and chemical products & CHEMICAL \\
\hline 7 & 25 & Rbber and plastics & RUBBER\&PLAST \\
\hline 8 & 326 & Other non-metallic mineral & NON-MET.MINERAL \\
\hline 9 & $27 \mathrm{t} 28$ & Basic metals and fabricated metal & METAL\&PRODUCT \\
\hline 10 & 29 & Machinery, nec & MACHINERY \\
\hline 11 & $30 t 33$ & Electrical and optical equipment & ELECTRIC\&OPTIC \\
\hline 12 & $34 t 35$ & Transport equipment & TRANSPORT \\
\hline 13 & $36 \mathrm{t} 37$ & Manufacturing nec; recycling & OTHER MFG \\
\hline
\end{tabular}

